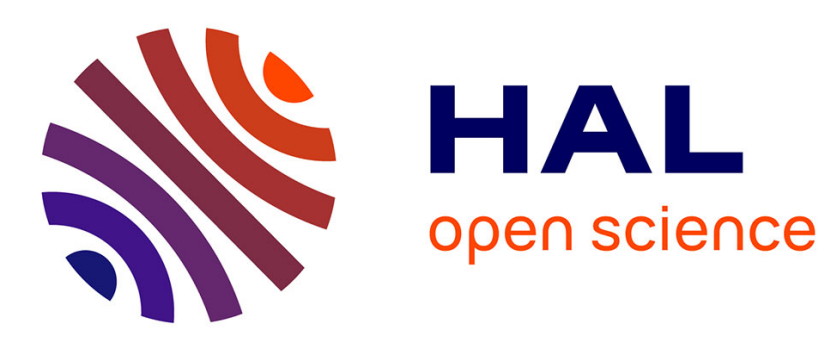

\title{
Transition to agriculture in South-Eastern Arabia: Insights from oral conditions
}

\author{
Olivia Munoz
}

\section{To cite this version:}

Olivia Munoz. Transition to agriculture in South-Eastern Arabia: Insights from oral conditions. American Journal of Physical Anthropology, 2017, 164 (4), pp.702-719. 10.1002/ajpa.23307 . hal01732648

\section{HAL Id: hal-01732648 \\ https://hal.science/hal-01732648}

Submitted on 6 Nov 2019

HAL is a multi-disciplinary open access archive for the deposit and dissemination of scientific research documents, whether they are published or not. The documents may come from teaching and research institutions in France or abroad, or from public or private research centers.
L'archive ouverte pluridisciplinaire HAL, est destinée au dépôt et à la diffusion de documents scientifiques de niveau recherche, publiés ou non, émanant des établissements d'enseignement et de recherche français ou étrangers, des laboratoires publics ou privés. 


\title{
Transition to agriculture in South-Eastern Arabia: Insights from oral conditions
}

\author{
Olivia Munoz
}

UMR 7041 - ArScAn, Team « Du village à I'État au Proche et Moyen-Orient ", Maison de l'Archéologie et de l'Ethnologie, 21 allée de l'Université, F-92023 Nanterre cedex,

France

\section{Correspondence}

Olivia Munoz, UMR 7041 ArScAn/VEPMO Team, Case 14, Maison de l'Archéologie et de l'Ethnologie, 21 allée de l'Université, F92023 Nanterre cedex, France.

Email: oliviamoz@gmail.com

\section{Funding information}

Scholarship from Université de Paris 1 Panthéon-Sorbonne, post-doctoral fellowship from Labex Les passés dans le présent, Investissements d'avenir, réf. ANR-11LABX-0026-01, and financial support from Fondation Fyssen (collaboration)

\begin{abstract}
Objectives: In Southeast (SE) Arabia, agriculture is supposed to expand around 3000 BC, but its tempo and its actual role in populations' subsistence is still debated by archaeologists. Here, we compare dental health conditions of 11 skeletal samples from coastal and inland sites, dated from the Late Neolithic (ca. 4500-3100 BC) to the Early Bronze Age (EBA), conventionally divided into Hafit (ca. 3100-2700 BC) and Umm an-Nar period (ca. 2700-2000 BC). The goal is to assess long-term trends in subsistence patterns and regional variability during the local transition to agriculture.
\end{abstract}

Methods: Seven indicators of oral health and childhood stress were analyzed, including dental wear, calculus, caries, alveolar resorption, periapical lesions, ante-mortem tooth loss (AMTL), and linear enamel hypoplasia (LEH).

Results: Neolithic coastal populations are globally characterized by high dental wear, high calculus frequency, high LEH frequency, and frequent periodontal disease, whereas they exhibit low abscesses and AMTL frequencies and a total absence of carious lesions. Samples from the Hafit period present high dental wear, low rates of calculus and LEH, frequent periodontal disease, combined with low abscess and AMTL frequencies and absence of caries. By contrast, samples from the Umm an-Nar period exhibit much lower dental wear, calculus and LEH rates, whereas caries, periapical lesions and AMTL frequencies increase significantly. Marked differences were observed between coastal and inland Umm an-Nar groups, the latter presenting significantly higher frequencies of caries, periapical lesions, alveolar resorption and AMTL.

Discussion/Conclusion: Oral conditions from the Neolithic coastal populations denote a diet mainly composed of unprocessed and abrasive food, with high protein and low carbohydrate intakes, and frequent stress episodes. Although Hafit populations display some changes in oral pathologies, which indicate modifications in their lifestyle and a diversification of the diet, no markers of high carbohydrate intakes were observed in our samples. The impact of agriculture on oral health appears clearly only from the Umm an-Nar period, and is more intense inland than on the coast, where marine resources are still a main component of the diet.

\section{KEYWORDS}

Bronze age, dental pathologies, diet, Neolithic, Oman Peninsula

\section{1 | INTRODUCTION}

In South-Eastern Arabia (present day United Arab Emirates and northern Sultanate of Oman, Figure 1), agriculture was adopted much later than in the neighboring regions like Mesopotamia or Iran, despite continual cultural contacts (Cleuziou, 2005; Potts, 2001). The Late Neolithic economy (ca. 4500-3100 BC) is mostly characterized by herding in the foothills areas and to a lesser extent, hunting (Uerpmann, Uerpmann, \& Jasim, 2008). Major occupations are known in coastal settlements, where zooarchaeological remains and geochemical 


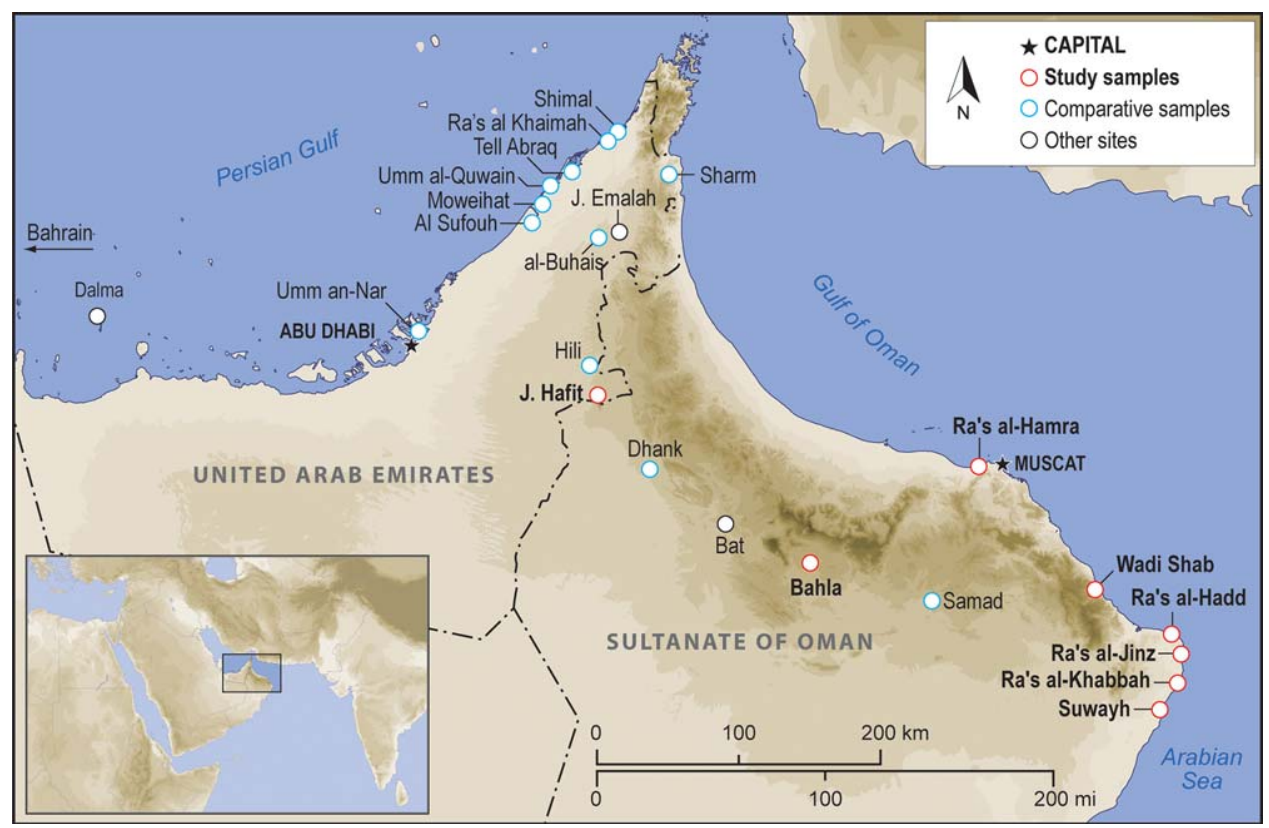

FIGURE 1 The Oman peninsula with site location

analyses on human remains attest to intensive exploitation of sea, lagoon, and mangrove resources associated with animal husbandry (Beech, 2004; Uerpmann, 2003; Zazzo, Munoz, \& Saliège, 2014). The first oasis agrosystems integrating date-palm and other plants cultivation are thought to appear and develop during the Early Bronze Age (EBA, ca. 3100-2000 BC) (Tengberg, 2012). But surprisingly, very little is known about the actual role of agriculture in the subsistence strategy of EBA societies, and its impact on their lifestyle. Oral conditions are strongly related to subsistence patterns and are particularly relevant to investigate the transition to an agricultural based diet. By analyzing dental pathologies from coastal and inland populations that predate and follow the appearance of agriculture in SE Arabia, this study aims to assess temporal and regional trends in subsistence economies.

Below, a review of paleobotanical, archaeological and anthropological evidence available for the region, shows that current knowledge on subsistence strategies is still limited. Paleobotanical studies suggest that during the Neolithic, vegetal exploitation was limited to wild species from the surrounding environments for fuel (Tengberg, 2008), tool-making and basketry (Munoz, 2014), dwelling construction, but also for consumption (Ziziphus sp.; Biagi \& Nisbet, 1992). Yet, two carbonized date-stones from palm-tree, radiocarbon dated from the late $6^{\text {th }}$-early $5^{\text {th }}$ mill. BC have been recovered at DA-11 (Dalma Island, $\mathrm{UAE}$ ), indicating that this fruit was consumed in the Persian Gulf at that time (Beech \& Shepherd, 2001). This evidence being unique for the Neolithic period in SE Arabia, the authors consider it with caution given the difficulty to determine whether it was wild or cultivated, local or imported.

Regarding the beginnings of the EBA, only four settlements from the Hafit period (ca. 3100-2700 BC) have been identified and excavated so far and paleobotanical evidence for agriculture is rare. At Hili 8 , a $3^{\text {rd }}$ millennium BC settlement located in the modern town of al-Ain (UAE), charred seeds and fragments of stems from date-palm, associated with charred grains and mud brick impressions of cereals were dated from the second half of the $3^{\text {rd }}$ millennium BC (Cleuziou \& Costantini, 1980). Although an earlier date was further proposed by Cleuziou and Costantini (1982), the absence of direct absolute dating does not allow a precise chronological attribution. At Ra's al-Hadd HD6, a fishing settlement from coastal Oman, charred date seeds have been recovered in Hafit layers dated from the first centuries of the $3^{\text {rd }}$ mill. BC, testifying of an early consumption of dates (Azzarà, 2012).

Most of the palaeobotanical evidence for date-palm and cereals cultivation are found in later Umm an-Nar contexts, both on coastal or inland settlements (e.g., Costantini \& Audisio, 2001; Willcox, 1995; Willcox \& Tengberg, 1995).

Other archaeological evidence has also been used to discuss the beginnings of agriculture in SE Arabia. Given the rarity of known settlements for the Hafit period, researchers have attempted to use the spatial distribution of Hafit funerary monuments-considered as territorial and resources markers-to infer socioeconomic organization of EBA societies. The results of such analyses seem somewhat contradictory: Cleuziou (2007, 2009) and Giraud (2009) estimate that some of the tombs from the Ja'alan (al-Sharqqiyah Governorate, Oman) are settled around arable lands where potential date-palm gardens could have been cultivated. Therefore, both authors hypothesize a sedentary or semi-sedentary agriculturalist subsistence. Conversely, Deadman (2012) considers that Hafit-type tombs identified by surveys in the Wadi Andam area (Central Oman) rather mark grazing lands, thus suggesting a nomadic pastoralist lifestyle. Based on surface collection of potsherds in the Wadi Andam area, al-Jahwari suggests that the development of sedentary agricultural lifestyle in the Oman peninsula started during the Umm an-Nar period, and was based on dense, smallscale rural occupation, marking therefore a substantial change with Hafit occupation and subsistence patterns, assumed as transhumant or entirely nomadic (Al-Jahwari, 2009, 2015). 
Even if paleobotanical and archaeological evidence are of primary interest to learn about the vegetal exploitation (either wild species or cultivated crops), possible dates of the first agricultural communities, and the existence of interior-coastal interactions and interchanges, they are of limited help to estimate the real part of agricultural products, as well as other resources in the human diet. By contrast, the study of dental conditions may provide more direct information on the dietary habits and contribute to better grasp the diversity of subsistence strategies adopted by ancient populations from South-Eastern Arabia.

The analysis of dental pathologies is frequently used to infer subsistence strategies of archaeological populations and is particularly relevant to characterize the transition to agriculture (e.g., Lukacs, 1989, 1992; Larsen, Shavit, \& Griffin, 1991; Turner, 1979). One of the most significant changes generated by the adoption of agriculture on a global scale is declining oral health resulting from the increase of carbohydrates in the diet, which became also softer and more processed. In several regions where these parameters have been analyzed, the frequency of carious lesions, abscesses, and ante-mortem tooth loss is usually greater in farming populations than among hunter-gatherers. However, some recent studies have underlined that such correlation was not systematic, since the nature of the cultivated crops and the diversity of food processing practices may have diverse consequences on oral health (e.g., Eshed, Gopher, \& Hershkovitz, 2006; Tayles, Domett, \& Nelsen, 2000).

In the context of SE Arabia, agriculture is based on the cultivation of date-palm, whose fruit is among the most cariogenic unprocessed food sources according to experimental study carried on rate (Stephan, 1966). Such cariogenicity is not surprising given its high fermentable sugar content (50-70\% of the dried fruit) and its soft and sticky consistency, both processed or not. Caries frequencies may thus be considered as a good indicator of agricultural development in the region (Nelson, Lukacs, \& Yule, 1999).

Over the last 30 years, several studies have documented dental pathologies in the Persian Gulf and in Eastern Arabia for Neolithic or Bronze Age populations (e.g., Blau, 2007; Bondioli, Coppa, \& Macchiarelli, 1998; Coppa \& Cucina, 2007; Højgaard, 1981; Kiesewetter, 2006; Littleton \& Frohlich, 1993; Macchiarelli, 1989). In their review and analysis of dental pathology in several skeletal samples from the Persian Gulf, Littleton and Frohlich (1993) proposed four main subsistence categories based on dental disease: (1) Fishers: severe attrition, low caries, low calculus (?), wear-caused abscessing, low AMTL; (2) Mixed (herders, fishers, and farmers): moderate to severe attrition, low caries, low to high calculus, wear-caused (?) abscesses, low to moderate AMTL calculus or wear-caused; (3) Mixed (farmers and herders): low to moderate attrition, high caries, high calculus, caries-caused abscesses, moderate to severe AMTL due to calculus and caries; (4) Farmers (intensive gardening): low attrition, high caries, low calculus, caries and wear-caused abscesses, severe AMTL related to caries. In between the two extremes pathological patterns related to intensive fishers and intensive agriculturalists, many groups present mixed profiles that are probably related to mixed economies.
By analyzing a set of dental health indicators from coastal and inland populations that predates and follows the appearance of agriculture in SE Arabia, our study aims to investigate diachronic and regional trends in subsistence economies. The present study will also contribute to fill the gap existing for the Hafit period and for coastal Oman. When discussing the results, special attention will be paid to the interplay between various oral conditions in order to decipher the origin of multi-factorial pathologies.

\section{2 | MATERIALS AND METHODS}

\section{1 | Sample collection}

Permanent dentitions from nine coastal funerary complexes dating from the Neolithic, Hafit, and Umm an-Nar periods and two inland necropolises from the Hafit and Umm an-Nar periods were included in the present study (Table 1, Figure 1). Details on the anthropological study, burial and archaeological contexts have been described elsewhere (Munoz, 2014), and will not be presented here for sake of brevity.

The preservation of both skeletal and dental remains was affected by several factors including arid environmental conditions, funerary practices, post-depositional disturbance, and curation of the material (Munoz, 2014). In addition to poor preservation of human remains, burial practices themselves create a problem for the comparison of samples. While the Neolithic funerary complexes are characterized by pit burials where individual skeletons can be distinguished, EBA communities used to deposit their dead in collective above-ground tombs over several generations, where fragmented human remains of numerous individuals are commingled (e.g., Munoz, 2015; Munoz, Ghazal, \& Guy, 2012). Thus, for the EBA collections, most of the jaws are fragmentary and most of the preserved teeth have been found isolated from their alveoli. The necessity to compare data from individual burials (Neolithic period) and commingled remains from collective burials (Hafit and Umm an-Nar periods) naturally led to favor a count per tooth or per alveolus rather than per individual. In order to maximize the sample size, both sides were combined in the analyses. In total, the study of dento-alveolar indicators has been performed on a total of 985 teeth and 983 alveoli (Table 1). Given the variable number of available teeth/ alveoli per site, data have been pooled by period and region in order to assess chronological and geographical variations with the largest possible samples.

\section{2 | Oral conditions}

Seven parameters were recorded, including dental wear, dental calculus, dental caries, alveolar resorption, periapical lesions, ante-mortem tooth loss (AMTL) and linear enamel hypoplasia (LEH). Only permanent and functional teeth have been taken into account in the present study, except for LEH, for which all permanent anterior teeth (incisors and canines) whose crown was completely mineralized were observed. When heavy wear or poor preservation limited the observation of a parameter such as calculus, caries, and LEH, the tooth was not taken into account for this parameter (not recordable condition). 
TABLE 1 Summary of the study sample

\begin{tabular}{|c|c|c|c|c|}
\hline PERIOD/REGION & $\begin{array}{l}\mathrm{N} \\
\text { Teeth }^{\mathrm{a}}\end{array}$ & $\begin{array}{l}\mathrm{N} \\
\text { Alveoli }^{\mathrm{a}}\end{array}$ & $\begin{array}{l}\mathrm{N} \\
\text { Adult indiv. }\end{array}$ & References \\
\hline \multicolumn{5}{|l|}{ Site (country)/Tomb \# } \\
\hline \multicolumn{5}{|l|}{ NEOLITHIC/COAST } \\
\hline Suwayh SWY-1 (Oman)/1, 2 & 42 & 21 & 2 & Charpentier et al., 2003; Munoz, 2014 \\
\hline Ra's al-Khabbah KHB-1 (Oman)/1, 2 & 31 & 30 & 2 & Munoz et al., 2010; Munoz, 2014 \\
\hline Wadi Shab GAS-1 (Oman)/1,8, 9, 13 & 64 & 45 & 4 & Gaultier et al., 2005; Munoz, 2014 \\
\hline $\begin{array}{l}\text { Ra's al-Hamra RH-6 (Oman)/1986/1, } \\
\text { 2000/1, 2012/1-2, 2013/5-6 }\end{array}$ & 126 & 80 & 6 & $\begin{array}{l}\text { Biagi, 1999; Marcucci et al., 2014; } \\
\text { Munoz, 2014; Zazzo et al., } 2016\end{array}$ \\
\hline $\begin{array}{l}\text { Ra's al-Hamra RH-5/2005-08 excavation } \\
\text { (Oman)/303A, 303B, 306A, 307, 314, } \\
\text { 320A, 320B, 326, 329B, 329D, 329E, } \\
\text { 405B, 405D, 411 }\end{array}$ & 332 & 212 & 14 & Munoz, 2014 \\
\hline
\end{tabular}

\section{HAFIT/COAST}

$\begin{array}{lllll}\text { Ra's al-Jinz RJ-6 (Oman)/2,3,5 } & 166 & 61 & 22^{*} & \text { Munoz, 2014; Santini, } 1992\end{array}$

\begin{tabular}{|c|c|c|c|c|}
\hline \multicolumn{5}{|l|}{ HAFIT/INLAND } \\
\hline Jebel Hafit (UAE)/2, 3 & 21 & 31 & $5^{*}$ & Cleuziou et al., 2011; Munoz 2011, 2014 \\
\hline \multicolumn{5}{|l|}{ UMM AN-NAR/COAST } \\
\hline Ra's al-Jinz RJ-1 (Oman)/T.1, Pits 1-3 & 59 & 319 & $47^{*}$ & $\begin{array}{l}\text { Monchablon et al., 2003; Munoz et al., } \\
\text { 2012; Munoz, } 2014\end{array}$ \\
\hline Ra's al-Jinz RJ-11 (Oman)/1 & 80 & 0 & $16^{*}$ & Munoz, 2014; Santini, 1992 \\
\hline Ra's al-Hadd HD-7 (Oman)/5 & 23 & 2 & $4^{*}$ & Munoz, 2014 \\
\hline \multicolumn{5}{|l|}{ UMM AN-NAR/INLAND } \\
\hline Bahla-Mosque (Oman)/Pit & 43 & 182 & $13^{*}$ & Munoz, 2014 \\
\hline TOTAL ${ }^{a}$ & 985 & 983 & 138 & \\
\hline
\end{tabular}

aMaximum number of teeth/alveoli examined; some parameters could not be recorded for all teeth/alveoli.

${ }^{\mathrm{b}}$ Number of adult individuals examined; * for collective tombs, the Minimum Number of Individuals is mentioned (details about osteological study and MNI determination are presented in Munoz, 2014).

Dental wear was recorded according to Smith (1984) which offers a scoring by tooth category (grades 1 to 8 ). Results are presented by mean grade and by frequency of teeth affected by heavy wear (HW, grades 7-8, little or no remaining enamel).

Dental calculus was broken down into three levels, as suggested by Brothwell (1981) and Buikstra and Ubelaker (1994).

Caries were evaluated macroscopically using a dental probe and were recorded according to standards proposed by Buikstra and Ubelaker (1994).

Alveolar resorption, or periodontal disease, was classified into four grades depending on the amount of root exposed $(0=$ absence; $1=$ slight, 1-3 mm; 2 = moderate, 3-5 mm; 3 = severe, $>5 \mathrm{~mm}$ ) according to Brothwell's (1981) visual system and Lukacs (1989) descriptive model.

Abscesses, or periapical lesions, were recorded according to Buikstra and Ubelaker (1994). This classification takes into account the location of the lesion $(0=$ absence; $1=$ buccal or labial alveolar channel, $2=$ lingual perforation).

Ante mortem tooth loss (AMTL) was recorded by alveolus. As only the partly or completely closed alveoli are counted, this probably underestimates the actual number of teeth lost ante mortem. However, this strategy is the only possible if one wants to compare both individual and commingled remains from different periods.
Linear enamel hypoplasias (LEH) was scored on anterior teeth (incisors and canines) according to Buikstra and Ubelaker (1994), with three stages of severity $(0=$ absence; $1=$ one line; $2=$ at least two lines of hypoplasia).

Descriptive statistics and Chi-Square tests were performed using "PAST", version 3.02a (Hammer, Harper, \& Ryan, 2001).

\section{3 | RESULTS}

The highly variable size of the study samples and their poor preservation obviously restricts what can be done in terms of analysis. In particular, since most of the factors-such as dental wear, periodontal disease, or ante-mortem tooth loss -are strongly age-related, their prevalence may be influenced by age distribution of the individuals in the samples. The Neolithic coastal samples contain a cross representation of adult ages (Munoz, 2014). The remaining samples consist of mixed remains, limiting in most cases individual age assessment, but apart from Jebel Hafit, most of the Bronze Age tombs include enough adult individuals to avoid major biases in the age distribution (Table 1). However, the difficulty in comparing the samples according to age of the individual, and the fragmentary nature of most of the samples requires a cautious approach when comparing the results. 


\section{AVERAGE ATTRITION}

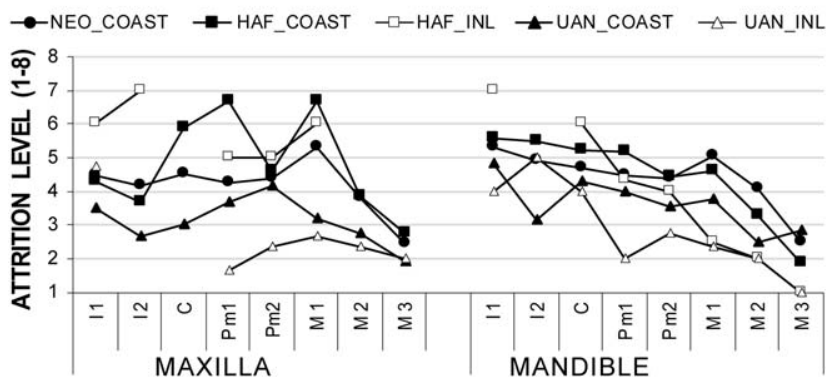

FIGURE 2 Average wear in Neolithic (NEO), Hafit (HAF) and Umm an-Nar (UAN) populations, in coastal (COAST) and inland (INL) regions

\section{1 | Dental wear}

Average wear and frequency of teeth affected by heavy wear are significantly higher in Neolithic (mean wear: 4.4, HW: 13.2\%) and Hafit populations (Inland: 4.4, 15\%; Coast:4.6, 19.5\%) than in Umm an-Nar groups (Inland: 2.9, 2.4\%; Coast: 3.4, 4.2\%) (Table 2, Figure 2) (HW Neolithic/Umm an-Nar: $\left.\chi^{2}=157.7656, \mathrm{df}=1, p=.00001\right)$. In Hafit and Umm an-Nar populations, no significant differences are found between coastal and inland mean wear. When considering the data by tooth type, in all samples, on the lower jaw, average wear roughly decreases from anterior toward posterior teeth, whereas some difference may be observed in the pattern of attrition across the maxillary dentition. For example, in the Hafit coastal upper teeth, first premolars and first molars demonstrate the heaviest wear rates (respectively 6.8 and 6.8 on average); in addition, a sharp gradient is observed in the mean wear between the molars, suggesting a rapid rate of attrition.
However, since the sample is rather small and contains only loose teeth, this result is difficult to interpret. For the smaller samples (Jebel Hafit and Bahla), the variations are likely to reflect the variable preservation of teeth and must be taken cautiously.

\section{2 | Calculus}

The frequency of calculus is significantly higher for both jaws in the Neolithic population (88\%) than in Hafit (52.4\%) and Umm an-Nar (43.8\%) groups (Table 3) (Neolithic/Hafit: $\chi^{2}=90.363, \quad \mathrm{df}=1$, $p=.00001 ;$ Neolithic/Umm an-Nar: $\chi^{2}=142.4867, \mathrm{df}=1, p=$ .00001). Inland groups present lesser calculus than coastal groups in Hafit (Inland $=30 \%$; Coast $=54.1 \%$ ) and Umm an-Nar (Inland $=36.6 \%$; Coast $=46.1 \%$ ) periods but the difference is not significant. All the types of teeth from the Neolithic population present similar calculus severity, whereas there is a variability for the other populations, maybe due to the small samples size and preservation (Figure 3). Calculus level 3 was found only in the Neolithic population (2.8\%), with the lower teeth (1.8\%) slightly less affected than upper ones (4\%).

\section{3 | Caries}

No carious lesion is observed in the Neolithic and the Hafit groups (Table 4, Figure 4). For the Umm an-Nar period, the caries rate is significantly higher in the inland population (21.7\%) than in the coastal population $(2.8 \%)\left(\chi^{2}=18.0497, \mathrm{df}=1, p=.000022\right)$. When analyzed by jaw, different results have also been observed: in the Umm an-Nar coastal group, caries were observed on the lower molars only; in the inland group, upper molars are more affected by caries (54.5\%) than lower molars (33.3\%), although the difference is not significant $\left(\chi^{2}=\right.$

TABLE 2 Average rate of attrition (scored 1-8) and heavy wear (HW) frequency by tooth, site, period and region ${ }^{\mathrm{a}}$

\begin{tabular}{|c|c|c|c|c|c|c|c|c|c|c|c|c|c|c|c|}
\hline \multirow[b]{2}{*}{ Jaw } & \multicolumn{3}{|c|}{ NEO_COAST } & \multicolumn{3}{|c|}{$\underline{\text { HAF_COAST }}$} & \multicolumn{3}{|c|}{ HAF_INL } & \multicolumn{3}{|c|}{ UAN_COAST } & \multicolumn{3}{|c|}{ UAN_INL } \\
\hline & $n$ & AVR & HW (\%) & $n$ & AVR & HW (\%) & $\mathrm{n}$ & AVR & HW (\%) & $\mathrm{n}$ & AVR & HW (\%) & $\mathrm{n}$ & AVR & HW (\%) \\
\hline \multicolumn{16}{|l|}{ Maxilla } \\
\hline $\mid 1$ & 36 & 4.5 & 8.3 & 20 & 4.3 & 0.0 & 2 & 6.0 & 0.0 & 29 & 3.5 & 0.0 & 4 & 4.8 & 0.0 \\
\hline 12 & 36 & 4.3 & 5.6 & 14 & 4.9 & 35.7 & 1 & 7.0 & 100 & 6 & 2.7 & 0.0 & 0 & - & - \\
\hline$C$ & 39 & 4.6 & 5.1 & 8 & 5.4 & 12.5 & 0 & - & - & 7 & 3.0 & 0.0 & 0 & - & - \\
\hline Pm1 & 37 & 4.4 & 10.8 & 6 & 6.8 & 66.7 & 2 & 5.0 & 0.0 & 6 & 3.7 & 16.7 & 3 & 1.7 & 0.0 \\
\hline $\mathrm{Pm} 2$ & 39 & 4.5 & 17.9 & 11 & 4.5 & 9.1 & 1 & 5.0 & 0.0 & 6 & 4.2 & 16.7 & 6 & 2.3 & 0.0 \\
\hline M1 & 39 & 5.4 & 28.2 & 4 & 6.8 & 75.0 & 1 & 6.0 & 0.0 & 5 & 3.2 & 0.0 & 7 & 3.3 & 14.3 \\
\hline M2 & 38 & 3.9 & 7.9 & 6 & 3.8 & 16.7 & 0 & - & - & 4 & 2.8 & 0.0 & 3 & 2.3 & 0.0 \\
\hline M3 & 35 & 2.3 & 0.0 & 8 & 2.8 & 0.0 & 0 & - & - & 9 & 2.0 & 0.0 & 1 & 2.0 & 0.0 \\
\hline \multicolumn{16}{|c|}{ Mandible } \\
\hline 11 & 27 & 5.3 & 25.9 & 14 & 5.6 & 28.6 & 2 & 7.0 & 100 & 6 & 4.8 & 33.3 & 1 & 4.0 & 0.0 \\
\hline 12 & 29 & 4.9 & 24.1 & 11 & 6.4 & 63.6 & 0 & - & - & 7 & 3.1 & 0.0 & 2 & 5.0 & 0.0 \\
\hline C & 34 & 4.8 & 5.9 & 12 & 4.8 & 8.3 & 1 & 6.0 & 0.0 & 10 & 4.3 & 0.0 & 2 & 4.0 & 0.0 \\
\hline Pm1 & 32 & 4.6 & 21.9 & 5 & 4.8 & 20.0 & 3 & 4.3 & 0.0 & 5 & 4.0 & 20.0 & 2 & 2.0 & 0.0 \\
\hline Pm2 & 37 & 4.4 & 18.9 & 11 & 3.8 & 18.2 & 1 & 4.0 & 0.0 & 16 & 3.6 & 6.3 & 4 & 2.8 & 0.0 \\
\hline M1 & 38 & 5.2 & 21.1 & 12 & 4.7 & 16.7 & 2 & 2.5 & 0.0 & 13 & 3.8 & 0.0 & 3 & 2.3 & 0.0 \\
\hline M2 & 41 & 4.2 & 12.2 & 14 & 3.3 & 0.0 & 2 & 2.0 & 0.0 & 9 & 2.6 & 0.0 & 3 & 2.0 & 0.0 \\
\hline M3 & 30 & 2.6 & 0.0 & 8 & 1.9 & 0.0 & 2 & 1.0 & 0.0 & 6 & 2.0 & 0.0 & 1 & 1.0 & 0.0 \\
\hline Otal & 567 & 4.4 & 13.2 & 164 & 4.6 & 19.5 & 20 & 4.4 & 15.0 & 144 & 3.4 & 4.2 & 42 & 2.9 & 2.4 \\
\hline
\end{tabular}

${ }^{a}$ NEO_COAST $=$ Neolithic Coastal populations; HAF_COAST $=$ Hafit Coastal population, HAF_INL $=$ Hafit Inland population; UAN_COAST $=$ Umm anNar Coastal populations; UAN_INL= Umm an-Nar Inland population; $n=$ total number of teeth examined; $A V R=$ Average; $H W=$ frequency of heavy wear (score 7-8). 
TABLE 3 Rate of calculus according to jaw by period and region ${ }^{2}$

\begin{tabular}{|c|c|c|c|c|c|c|c|c|c|c|}
\hline \multirow[b]{2}{*}{ Calculus level ${ }^{\mathrm{b}}$} & \multirow[b]{2}{*}{ Jaw } & \multicolumn{4}{|c|}{$\mathrm{N}$ of teeth affected } & \multicolumn{4}{|c|}{ Calculus rate (\%) } & \multirow[b]{2}{*}{ Total $^{\mathrm{C}}$} \\
\hline & & 1 & 2 & 3 & Sum & 1 & 2 & 3 & Total & \\
\hline \multicolumn{11}{|l|}{ Population } \\
\hline \multirow[t]{2}{*}{ NEO_COAST } & Maxilla & 219 & 21 & 5 & 245 & 79.1 & 7.6 & 1.8 & 88.4 & 277 \\
\hline & Mandible & 186 & 22 & 10 & 218 & 74.7 & 8.8 & 4.0 & 87.6 & 249 \\
\hline \multirow[t]{2}{*}{ HAF_COAST } & Maxilla & 38 & 0 & 0 & 38 & 60.3 & 0.0 & 0.0 & 60.3 & 63 \\
\hline & Mandible & 33 & 1 & 0 & 34 & 47.1 & 1.4 & 0.0 & 48.6 & 70 \\
\hline \multirow[t]{2}{*}{ HAF_INL } & Maxilla & - & - & - & - & - & - & - & - & 0 \\
\hline & Mandible & 3 & 0 & 0 & 3 & 30.0 & 0.0 & 0.0 & 30.0 & 10 \\
\hline \multirow[t]{2}{*}{ UAN_COAST } & Maxilla & 16 & 0 & 0 & 16 & 24.2 & 0.0 & 0.0 & 24.2 & 66 \\
\hline & Mandible & 41 & 2 & 0 & 43 & 66.1 & 3.2 & 0.0 & 69.4 & 62 \\
\hline \multirow[t]{2}{*}{ UAN_INL } & Maxilla & 7 & 0 & 0 & 7 & 29.2 & 0.0 & 0.0 & 29.2 & 24 \\
\hline & Mandible & 8 & 0 & 0 & 8 & 47.1 & 0.0 & 0.0 & 47.1 & 17 \\
\hline
\end{tabular}

${ }^{a}$ NEO_COAST $=$ Neolithic Coastal populations; HAF_COAST = Hafit Coastal population, HAF_INL= Hafit Inland population; UAN_COAST $=$ Umm anNar Coastal populations; UAN_INL= Umm an-Nar Inland population.

${ }^{\mathrm{b}}$ According to Brothwell (1981): 1 = slight; 2 = moderate; $3=$ severe.

${ }^{\mathrm{c}}$ Total number of examined teeth.

0.7012, $\mathrm{df}=1, p=.402388$ ), and carious lesions are also observed on lower premolars.

\section{4 | Alveolar resorption}

Alveolar resorption means range from 1.7 to 2.1 , with 89.6 to $100 \%$ of alveoli showing resorption, which indicates a high occurrence of periodontal disease for all groups (Table 5, Figure 5). Neolithic groups display on average $21.4 \%$ of alveoli affected by severe resorption, while Hafit coastal (9.8\%) and inland (12.0\%) groups show significantly lower mean values (Neolithic/Hafit: $\chi^{2}=5.2939, \mathrm{df}=1, p=.021401$ ). In Umm an-Nar coastal groups (21.5\%) severe resorption is as common as in Neolithic groups, while it is much higher inland, with almost half of the alveoli affected (44.4\%) (UaN Coast/Inland: $\chi^{2}=26.153, \mathrm{df}=1$, $p<.00001)$. Furthermore, different patterns emerge when the data are grouped by category of tooth, suggesting that periodontal disease may have different causes across time and space. For example, in the Neolithic mandibles, similar AR levels are recorded on anterior teeth (2.0)

\section{AVERAGE CALCULUS}

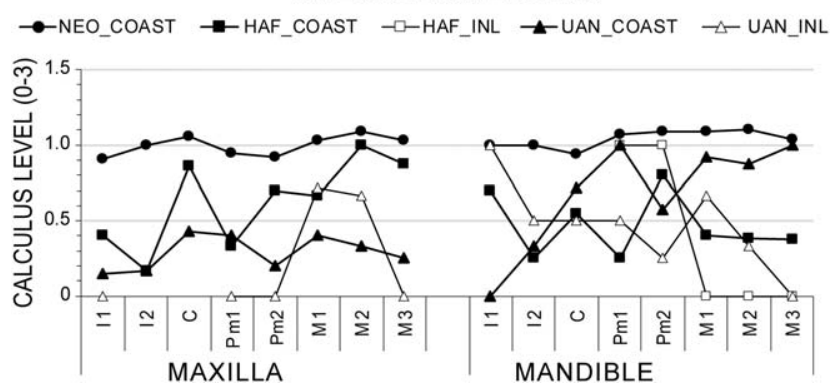

FIGURE 3 Average calculus in Neolithic (NEO), Hafit (HAF) and Umm an-Nar (UAN) populations, in coastal (COAST) and inland (INL) regions and molars (1.9); by contrast, the Umm an-Nar coastal and inland sample show higher resorption rates on molars (respectively 2.2 and 2.6) than on anterior alveoli (1.8 and 1.8). In between, in the Hafit coastal and inland groups, anterior teeth are slightly less affected than molars.

\section{5 | Periapical lesions}

On the coast, there is a gradual increase of abscessing from Neolithic (7.3\%) to EBA (Hafit coastal $=11.5 \%$, Umm an-Nar coastal $=15.8 \%$ ) (Tab. 5, Figure 6), but the difference from one period to the next is not statistically significant. No regional differences have been found for the Hafit populations, although the small size of the samples requires circumspection. By contrast, the Umm an-Nar inland population (31.7\%) is significantly much more affected by periapical lesions than the coastal one (15.8\%) ( $\left.\chi^{2}=15.5225, \mathrm{df}=1, p=.000082\right)$. Upper jaws are more affected by abscessing than mandibles in Neolithic coastal group and in Umm an-Nar coastal and inland groups. Such difference is difficult to assess in Hafit coastal and inland groups, since very few maxillae are available.

\section{6 | AMTL}

The Neolithic coastal groups have the lowest frequencies of AMTL (5.2\%) (Table 5, Figure 7). For the Hafit period the frequency is significantly higher on the coast (13.1\%), but is moderate inland (6.5\%). The Umm an-Nar groups show higher frequencies than former groups, either on the coast (24.7\%) (UaN coast/Neolithic: $\chi^{2}=54.6837, \mathrm{df}=1$, $p<.00001$ ) or inland (31.3\%) (UaN Inland/Neolithic: $\chi^{2}=72.5855$, $\mathrm{df}=1, p<.00001)$. Several edentulous mandibles were indeed observed at RJ-1 and Bahla. Interestingly, the distribution of AMTL across the mouth show different patterns according to the periods. In the Neolithic mandibles AMTL frequencies decrease from the central 
TABLE 4 Rates of caries by period and region ${ }^{\mathrm{a}}$

\begin{tabular}{|c|c|c|c|c|c|c|c|c|c|c|}
\hline \multirow[b]{2}{*}{ Jaw } & \multicolumn{2}{|c|}{ NEO_COAST } & \multicolumn{2}{|c|}{ HAF_COAST } & \multicolumn{2}{|c|}{ HAF_INL } & \multicolumn{2}{|c|}{ UAN_COAST } & \multicolumn{2}{|c|}{ UAN_INL } \\
\hline & $\mathbf{N}$ & $\%$ & $\mathrm{~N}$ & $\%$ & $\mathrm{~N}$ & $\%$ & $\mathrm{~N}$ & $\%$ & $\mathrm{~N}$ & $\%$ \\
\hline \multicolumn{11}{|l|}{ Maxilla } \\
\hline I1 & 36 & 0.0 & 20 & 0.0 & 0 & - & 29 & 0.0 & 5 & 0.0 \\
\hline 12 & 36 & 0.0 & 13 & 0.0 & 0 & - & 5 & 0.0 & 1 & 0.0 \\
\hline $\mathrm{C}$ & 39 & 0.0 & 7 & 0.0 & 0 & - & 7 & 0.0 & 1 & 0.0 \\
\hline Pm1 & 37 & 0.0 & 5 & 0.0 & 0 & - & 6 & 0.0 & 4 & 0.0 \\
\hline Pm2 & 39 & 0.0 & 10 & 0.0 & 0 & - & 6 & 0.0 & 6 & 0.0 \\
\hline M1 & 39 & 0.0 & 3 & 0.0 & 0 & - & 5 & 0.0 & 7 & 28.6 \\
\hline M2 & 38 & 0.0 & 6 & 0.0 & 0 & - & 4 & 0.0 & 3 & 100 \\
\hline M3 & 35 & 0.0 & 9 & 0.0 & 0 & - & 9 & 0.0 & 1 & 100 \\
\hline \multicolumn{11}{|c|}{ Mandible } \\
\hline 11 & 26 & 0.0 & 14 & 0.0 & 0 & - & 4 & 0.0 & 1 & 0.0 \\
\hline 12 & 28 & 0.0 & 11 & 0.0 & 0 & - & 7 & 0.0 & 2 & 0.0 \\
\hline C & 34 & 0.0 & 12 & 0.0 & 0 & - & 10 & 0.0 & 2 & 0.0 \\
\hline Pm1 & 32 & 0.0 & 5 & 0.0 & 2 & 0.0 & 5 & 0.0 & 2 & 50.0 \\
\hline $\mathrm{Pm} 2$ & 37 & 0.0 & 11 & 0.0 & 1 & 0.0 & 16 & 0.0 & 5 & 20.0 \\
\hline M1 & 38 & 0.0 & 12 & 0.0 & 2 & 0.0 & 13 & 23.1 & 3 & 33.3 \\
\hline M2 & 41 & 0.0 & 14 & 0.0 & 2 & 0.0 & 9 & 11.1 & 3 & 33.3 \\
\hline M3 & 30 & 0.0 & 7 & 0.0 & 3 & 0.0 & 7 & 0.0 & 0 & - \\
\hline Total & 565 & 0.0 & 159 & 0.0 & 10 & 0.0 & 142 & 2.8 & 46 & 21.7 \\
\hline
\end{tabular}

${ }^{a}$ NEO_COAST $=$ Neolithic Coastal populations; HAF_COAST $=$ Hafit Coastal population. HAF_INL $=$ Hafit Inland population; UAN_COAST $=$ Umm anNar Coastal populations; UAN_INL= Umm an-Nar Inland population; $N=$ Number of examined teeth.

incisors (18.8\%) to the first premolars (4.2\%) and except for the third molar (15.4\%), no posterior teeth are lost antemortem. Such a result contrasts with EBA samples were posterior dentition is on average more affected by AMTL, especially in the Umm an-Nar groups. These different patterns may indicate different etiologies for tooth losses according to the periods.

\section{$3.7 \mid$ LEH}

On average, LEH are significantly more frequent in the Neolithic groups $(67.6 \%)$ than during the subsequent periods (Neolithic/Hafit coast: $\chi^{2}=18.5466, \mathrm{df}=1, p=.000017$; Neolithic/UaN Coast: $\chi^{2}=$ 13.2384, $\mathrm{df}=1, p=.000274$ ), while no difference is found between Hafit and Umm an-Nar samples (from 33.3 to 34.5\%) (Table 6). However, no data are available for the Hafit inland group, and very few anterior teeth were observable for both coastal and inland Umm an-

\section{RATES OF CARIES}

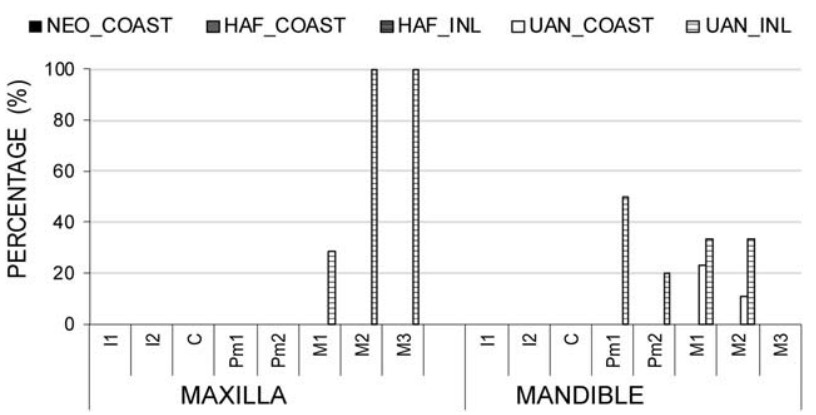

FIGURE 4 Caries frequency in Neolithic (NEO), Hafit (HAF) and Umm an-Nar (UAN) populations, in coastal (COAST) and inland (INL) regions
Nar groups, which weakens the results, enlarges confidence intervals and limits a regional comparison for the EBA.

\section{4 | DISCUSSION}

Based on the analysis of the dental health from 11 prehistoric populations from coastal and inland zones of South-Eastern Arabia, the aim of the present study was to explore dietary habits in a time span which encompasses the adoption of agriculture in this region, in order to detect its impact and to assess its actual part in the groups' subsistence. Some limitations have been encountered due to the poor state of preservation of dento-alveolar remains and the discrepancy between samples sizes. In particular, the overall fragmentation of the material and the commingled nature of dental and osteological assemblages in EBA tombs prevent taking into account the factors of age and sex in the analysis. In addition, the inland group from Hafit period (Jebel Hafit) is represented only by a few teeth and mandible fragments. Among Umm anNar populations, while few teeth were observable for the inland sample (Bahla), coastal sites provided no (RJ-11) or rare (HD-7) observable alveoli, or few teeth (RJ-1, HD-7). Nevertheless, when pooled by period and region, several variations in the pattern of dental disease may be observed according to periods and regions (Table 7, Figure 8). The dental patterns observed are discussed below and compared to data published in the Gulf region and Oman Peninsula (Table 8, Figure 1).

\subsection{Subsistence patterns from the neolithic to the EBA: regional trends}

\subsection{1 | Neolithic coastal populations}

Although the site-to-site variability-not analyzed here because of the small sample sizes available-may reveal a more complex picture, the 


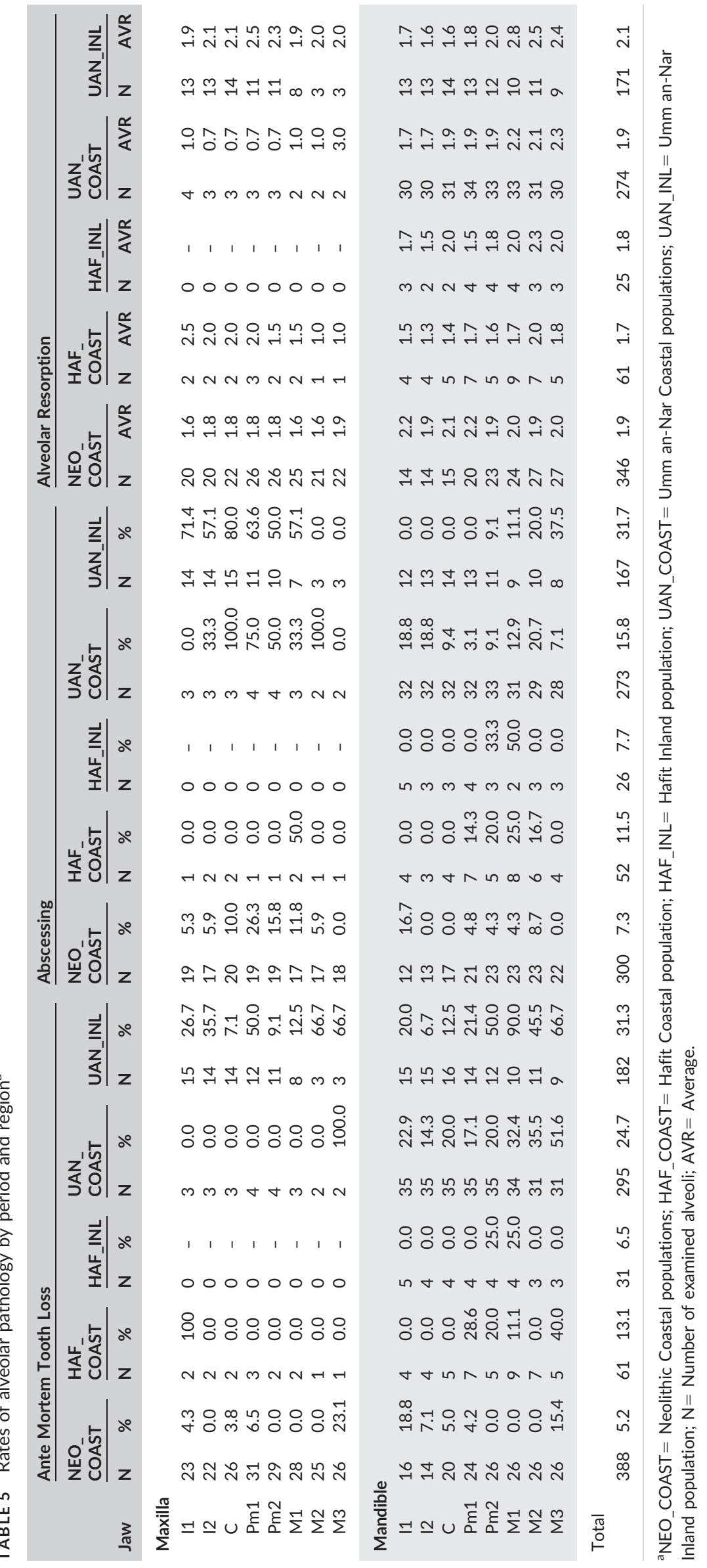


AVERAGE ALVEOLAR RESORPTION

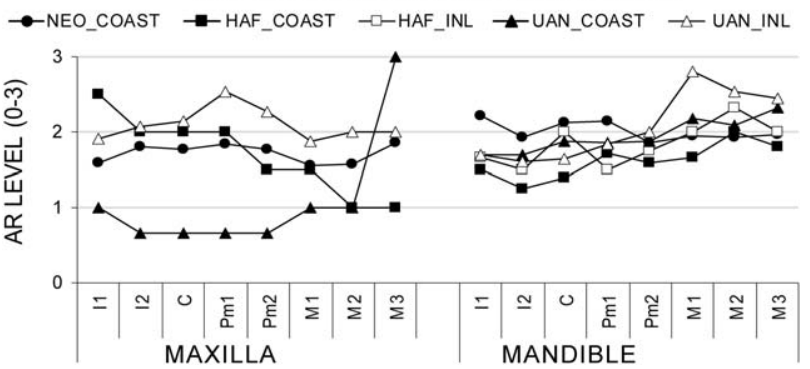

FIGURE 5 Average alveolar resorption in Neolithic (Neo), Hafit (HAF) and Umm an-Nar (UAN) populations, in coastal (COAST) and inland (INL) regions

dental conditions of the Neolithic coastal population are globally characterized by a high dental wear, more important on lower anterior teeth, combined with important calculus rates, high LEH frequency, and frequent periodontal diseases as demonstrated by the high rates of alveolar resorption. On the other hand, they show low abscesses and AMTL frequencies, and a total absence of carious lesions. In keeping with previous studies carried on other coastal Neolithic samples from the region (Ra's al-Hamra RH-5, 1980's excavation: inter alia Bondioli, Coppa \& Macchiarelli, 1998; Coppa \& Cucina, 2007; Macchiarelli, 1989; Umm al-Quwain Site 2: Blau, 2007), this dental pattern corresponds to the "fishers" described by Littleton and Frohlich (1993) for the Persian Gulf and to the marine-dependent dental profile (MDDP) described by Selwood (2010). It denotes a diet relying basically on protein rich, unprocessed food requiring intensive mastication, with an abrasive consistency. Our results are consistent with zooarchaeological, geochemical analyses, and archaeological data available from the associated Neolithic coastal settlements. The faunal assemblages indeed reflect an intense exploitation of marine and coastal resources, such as fish, shellfish, marine mammals and turtles, and more casually, consumption of terrestrial domesticated mammals (Charpentier, Marquis, \& Pellé, 2003; Marcucci et al., 2014; Munoz, Scaruffi, \& Cavulli, 2010; Uerpmann, 2003; Usai, 2006). Geochemical analyses performed on human bone from RH-5 and RH-6 confirmed also a subsistence economy mainly oriented toward coastal resources (Zazzo, Munoz \&

\section{RATES OF PERIAPICAL LESIONS}

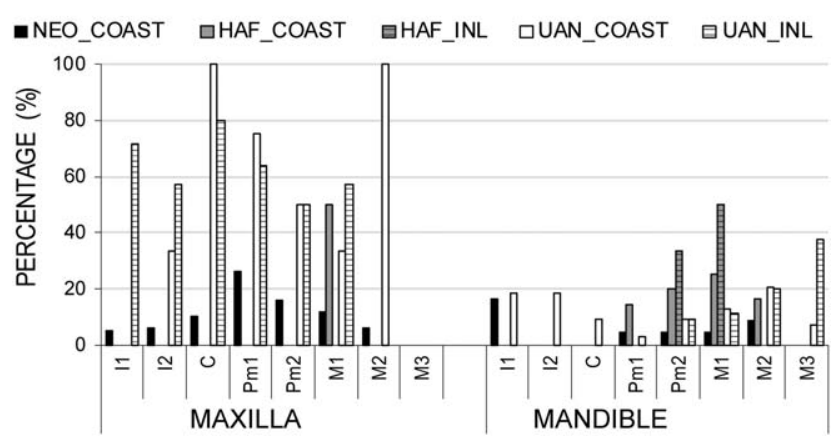

FIGURE 6 Abscessing frequency in Neolithic (NEO), Hafit (HAF) and Umm an-Nar (UAN) populations, in coastal (COAST) and inland (INL) regions
RATES OF AMTL

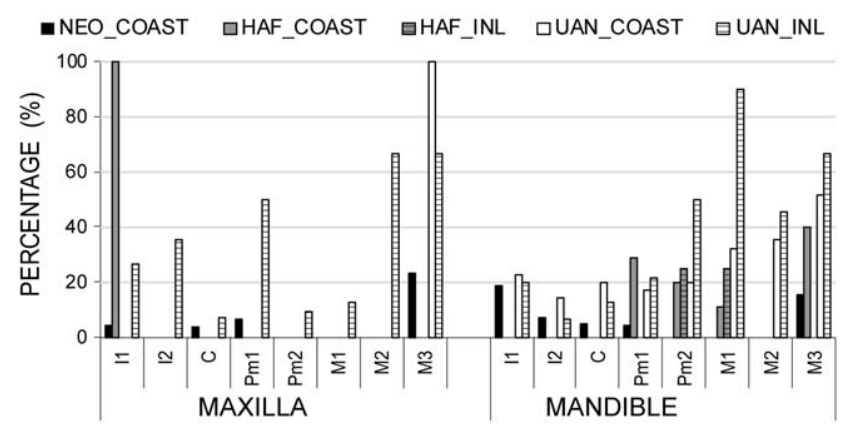

FIGURE 7 Ante Mortem Tooth Loss (AMTL) frequency in Neolithic (NEO), Hafit (HAF) and Umm an-Nar (UAN) populations, in coastal (COAST) and inland (INL) regions

Saliége, 2014 Zazzo et al., 2016). Regarding the abrasive nature of the food, excavations carried on contemporaneous settlements at SWY-2, $\mathrm{RH}-5$, and $\mathrm{RH}-6$ have brought to light several structures that could have been used to cure and store dried or smoked fish (Charpentier, Blin, \& Tosi, 1998; Marcucci et al., 2011, 2014). These preservation techniques, also reported by ethnography (El-Mahi, 2000), could have been a contributing factor for heavy wear, as grit would have been repeatedly integrated into the food. In this regard, microscopical analyses of calculus deposits from two individuals from $\mathrm{RH}-5$ and KHB-1 indicated the presence of crystals that may come from windblown sand, and could have been integrated when consuming dried fish or meat (Charlier et al., 2010). The use of grinding stones, found at GAS1, KHB-1, and RH-5 (Cavulli \& Scaruffi 2008; Gaultier et al., 2005; Salvatori, 2007), could also have contributed to introduce fine abrasive particles to the food, although the nature of crushed materials-alimentary or not-has not been investigated.

In addition to the severe attrition related to the abrasive nature of the food, the high frequency of chipping and fractures affecting the teeth in these groups (Munoz, 2014) indicates the widespread and intense solicitation of the teeth for processing hard components. Given the aceramic nature of the study sites, cooking methods were probably rudimentary and probably did not help to soften food. Such heavy use of teeth is also attested by several cases of severe hypercementosis (Tang, Le Cabec, \& Antoine, 2015) remarked in all the Neolithic samples, as well as some cases of cementicles (at GAS-1 and SWY-1) (Munoz, 2014). As both formations are due to chronic periodontal inflammations that can be caused by repeated mechanical stress (occlusion forces), they could result of an intense use of teeth both for alimentary and occupational purposes.

The total absence of caries in our Neolithic coastal samples may be partly related to the heavy wear characterizing these populations, which could have played a preventive role against caries development, by grinding the occlusal surface of the teeth (Maat \& Van der Velde, 1987). Together, the low levels of other diseases usually related to high carbohydrate intakes (abscesses and AMTL) suggest that fruits or seeds did not likely play a major role in the diet, although the consumption of Ziziphus fruits is reported at RH-5 and RH-6 (Biagi \& Nisbet, 1992). For these Neolithic coastal groups, abscesses and AMTL are rather 
TABLE 6 Summary of LEH data (permanent anterior teeth only)

\begin{tabular}{|c|c|c|c|c|c|c|c|c|}
\hline \multirow[b]{2}{*}{ By tooth } & & \multicolumn{3}{|c|}{ Maxilla } & \multicolumn{3}{|c|}{ Mandible } & \multirow[b]{2}{*}{ All } \\
\hline & & 11 & 12 & $\mathrm{C}$ & I1 & 12 & C & \\
\hline \multirow[t]{3}{*}{ NEO_COAST } & $\mathrm{N}$ & 28 & 33 & 32 & 9 & 15 & 25 & 142 \\
\hline & \%LEH & 75.0 & 60.6 & 75.0 & 33.3 & 53.3 & 80.0 & 67.6 \\
\hline & \%SLEH & 21.4 & 9.1 & 12.5 & 11.1 & 0.0 & 8.0 & 11.3 \\
\hline \multirow[t]{3}{*}{ HAF_COAST } & $\mathrm{N}$ & 21 & 6 & 11 & 7 & 4 & 9 & 58 \\
\hline & \%LEH & 28.6 & 50.0 & 81.8 & 0.0 & 0.0 & 22.2 & 34.5 \\
\hline & \%SLEH & 0.0 & 0.0 & 0.0 & 0.0 & 0.0 & 0.0 & 0.0 \\
\hline \multirow[t]{3}{*}{ HAF_INLAND } & $\mathrm{N}$ & 0 & 0 & 0 & 0 & 0 & 0 & 0 \\
\hline & \%LEH & - & - & - & - & - & - & - \\
\hline & \%SLEH & - & - & - & - & - & - & - \\
\hline \multirow[t]{3}{*}{ UAN_COAST } & $N$ & 31 & 0 & 0 & 0 & 0 & 2 & 33 \\
\hline & \%LEH & 29.0 & - & - & - & - & 100.0 & 33.3 \\
\hline & \%SLEH & 9.7 & - & - & - & - & 100.0 & 15.2 \\
\hline \multirow[t]{3}{*}{ UAN_INLAND } & $\mathrm{N}$ & 4 & 0 & 0 & 1 & 2 & 2 & 9 \\
\hline & \%LEH & 50.0 & - & - & 0.0 & 50.0 & 0.0 & 33.3 \\
\hline & \%SLEH & 0.0 & - & - & 0.0 & 0.0 & 0.0 & 0.0 \\
\hline
\end{tabular}

${ }^{\text {aNEO }}$ COAST $=$ Neolithic Coastal populations; HAF_COAST = Hafit Coastal population, HAF_INL= Hafit Inland population; UAN_COAST = Umm anNar Coastal populations; UAN_INL= Umm an-Nar Inland population; $\mathrm{N}=$ Number of examined teeth; \%LEH = Frequency of teeth affected by LEH (grade $\geq 1$ ); \%SLEH = Frequency of teeth affected by severe LEH (grade 2) according to Buikstra and Ubelaker (1994).

provoked by pulp exposure subsequent to wear (Macchiarelli, 1989) and dental fractures (Munoz, 2014). In addition, periodontal disease and alveolar resorption caused by large calculus accumulations may have resulted ultimately in tooth losses (Lukacs, 2007).

Finally, the high levels of LEH (67.6\%) recorded testify of recurrent physiological stresses among these populations, and are consistent, although lower in frequency, with previous studies carried on a wide sample from $\mathrm{RH}-5$ revealing that $95.4 \%$ of the 371 anterior tooth recorded had at least one hypoplastic defect (Coppa \& Cucina, 2007).
High frequency of LEH in a population has been ascribed to conditions of endemic mild-to-moderate malnutrition (Goodman \& Rose, 1991). In the Neolithic coastal context, nutritional deficiencies may have been caused by a weakly diversified diet and the nonpermanent availability of the resources exploited. Such widespread deficiencies related to a highly specialized diet, marine-protein-based, may also be reflected by the high prevalence of spina bifida reported in the same Neolithic skeletal samples (Coppa \& Cucina, 2007; Gaultier et al., 2005; Munoz, 2014). Despite a strong genetic load for this ossification defect of the

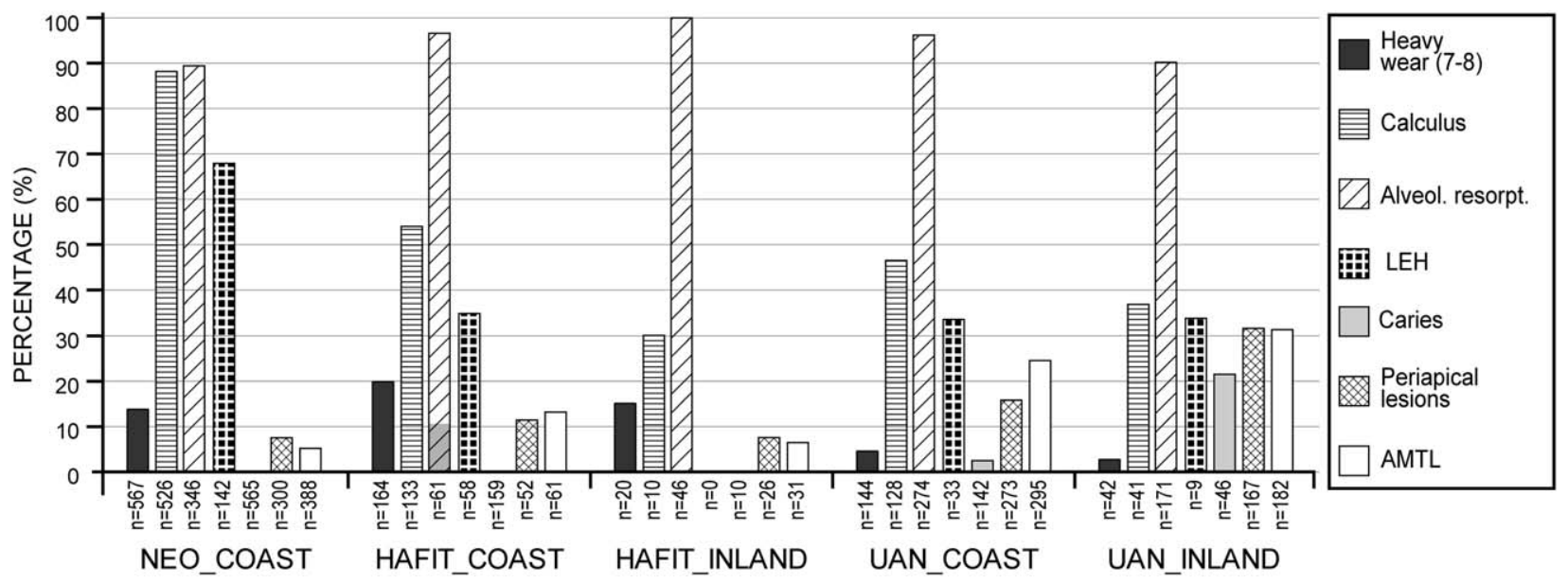

FIGURE 8 Average rates of oral pathologies in Neolithic (NEO), Hafit (HAF) and Umm an-Nar (UAN) populations, in coastal (COAST) and inland (INL) regions 
TABLE 7 Main patterns by period and region

\begin{tabular}{|c|c|c|c|c|c|}
\hline & Neolithic Coast & Hafit Coast & Hafit Inland & Umm an-Nar Coast & Umm an-Nar Inland \\
\hline Wear & ++ & ++ & ++ & + & + \\
\hline Calculus & ++ & + & + & + & + \\
\hline LEH & ++ & + & nd & + & + \\
\hline Alveolar resorption & ++ & ++ & ++ & ++ & ++ \\
\hline Periapical lesions & - & + & - & + & ++ \\
\hline AMTL & - & + & - & ++ & +++ \\
\hline Caries & 0 & 0 & 0 & - & ++ \\
\hline
\end{tabular}

$\mathrm{Nd}=$ no data; $\mathrm{O}=$ Absent $;-=$ Low $+=$ Moderate $++=$ High; $+++=$ Very high.

neural arch of the sacrum, reflecting a high degree of endogamy in the groups (Coppa \& Cucina, 2007; Macchiarelli, 1989), the risk is known to be reduced by up to $70 \%$ by an adequate intake of folic acid during pregnancy (Green \& Copp, 2014), which is naturally present in several vegetables (e.g. peas, beans, broccoli) and herbs (e.g. cress, spinach), in animal liver, goat dry cheese, and to a lesser extent in uncooked egg yolk. High spina bifida prevalence could therefore reflect both endogamy and a diet poor in vegetables.

\subsubsection{Comparison with an inland neolithic population}

Data published by Kiesewetter (2006) allow comparing our Neolithic coastal samples with the group buried in the inland foothills, at alBuhais BHS-18 (Sharjah Emirate), at the end of the $5^{\text {th }}$ mill. BC. Interestingly, dental diseases from BHS-18 show some similarity with our coastal samples, specifically concerning the absence of carious lesions $(0 \%)$ and the low frequencies of abscesses (1.2\%) and AMTL (2\%) (Table 8). For the latter two parameters the frequencies are even significantly lower in the BHS-18 population than in our coastal samples (abscess: $\chi^{2}=51.304, \mathrm{df}=1, p=.00001$; AMTL: $\left(\chi^{2}=13.4705, \mathrm{df}=1\right.$, $p=.00024)$. In addition, alveolar resorption is said to have been common in the BHS-18 group, but the exact frequency is not mentioned. Despite the absence of data per tooth that prevents a precise comparison, some differences have to be noted: on average, the proportion of teeth affected by HW (7.2\%) is significantly lower than in our coastal samples (13.2\%) $\left(\chi^{2}=26.1725, \mathrm{df}=1, p=.00001\right)$. For LEH, use of a different scoring method prevents a comparison with our samples (LEH is recorded for all categories of teeth, and affects $4.8 \%$ of the teeth). According to the author, the group' subsistence was mainly based on herding with probable seasonal mobility toward the coast (Kiesewetter, 2006), that could explain the similarities with our coastal samples.

\subsection{3 | Hafit coastal population}

One of the scopes of our study was to fill the gap for the Hafit Period and the coastal region, so far underrepresented in anthropological studies dedicated to EBA in South-Eastern Arabia. The Hafit coastal population from Ra's al-Jinz RJ-6 display a slightly distinct pattern compared to its Neolithic counterparts, which reflects some modification in the diet and lifestyle. Indeed, compared to Neolithic samples the group buried at RJ-6 present significantly lower calculus $\left(\chi^{2}=79.8042, \mathrm{df}=1\right.$, $p<.01)$ and LEH $\left(\chi^{2}=18.547, \mathrm{df}=1, p<.01\right)$, higher HW $\left(\chi^{2}=4.02\right.$, $\mathrm{df}=1, \quad p<.05), \quad$ AMTL $\left(\chi^{2}=5.7122, \quad \mathrm{df}=1, \quad p=.02\right)$, severe AR $\left(\chi^{2}=3.11, \mathrm{df}=1, p<.08\right)$ and is slightly more affected by abscesses, although it displays no carious lesion. The lower calculus frequency and severity may reflect a growing diversification of the diet, less proteinbased, as well as better oral hygiene. The first hypothesis is supported by the concomitant significant decrease of LEH frequency observed on the coast. In fact, a diet based on diversified resources would have allowed a greater control in food supply (fewer starvation episodes), and at the same time a larger variety of food (fewer deficiencies) that would have contributed to the diminution of metabolic stress. Concomitantly Hafit coastal group display similar mean wear to Neolithic populations, which may be due to the permanence of alimentary practices involving abrasive food, such as dried fish. In this regard, archaeological and zooarchaeological evidence from the neighboring Hafit settlement (Ra's al-Hadd HD-6) point to heavy exploitation of marine resources, as attested by the large quantity of fishing implements and several communal ovens dedicated to fish processing, as well as a faunal assemblage largely dominated by marine animals (Azzarà, 2012). In addition, the spread of use of grinding stones and pestles for food processing is well attested at HD-6 (Azzarà, 2012). Such practice could have been responsible of an increase of $\mathrm{HW}$, by adding hard particles into the food.

Interestingly, the combined increase of abscesses, severe alveolar resorption, and AMTL might suggest that other factors than calculus are involved in these diseases and could point toward an increasing part of carbohydrates in the diet, although no caries are recorded. For these three parameters, the frequency in our Hafit coastal sample lies in an intermediate position between Neolithic and Umm an-Nar coastal samples, suggesting gradual change in the diet. Accordingly, the pattern of distribution of alveolar resorption across the mouth shows also an intermediate position between Neolithic and Umm an-Nar coastal samples. Moreover, compared to the Neolithic coastal groups, the distribution of abscesses, AMTL and alveolar resorption on the mandible displays different patterns, with premolars and molars more affected than anterior teeth, which would confirm a dietary change compared to the Neolithic. Nevertheless, the increase of pathologies commonly 


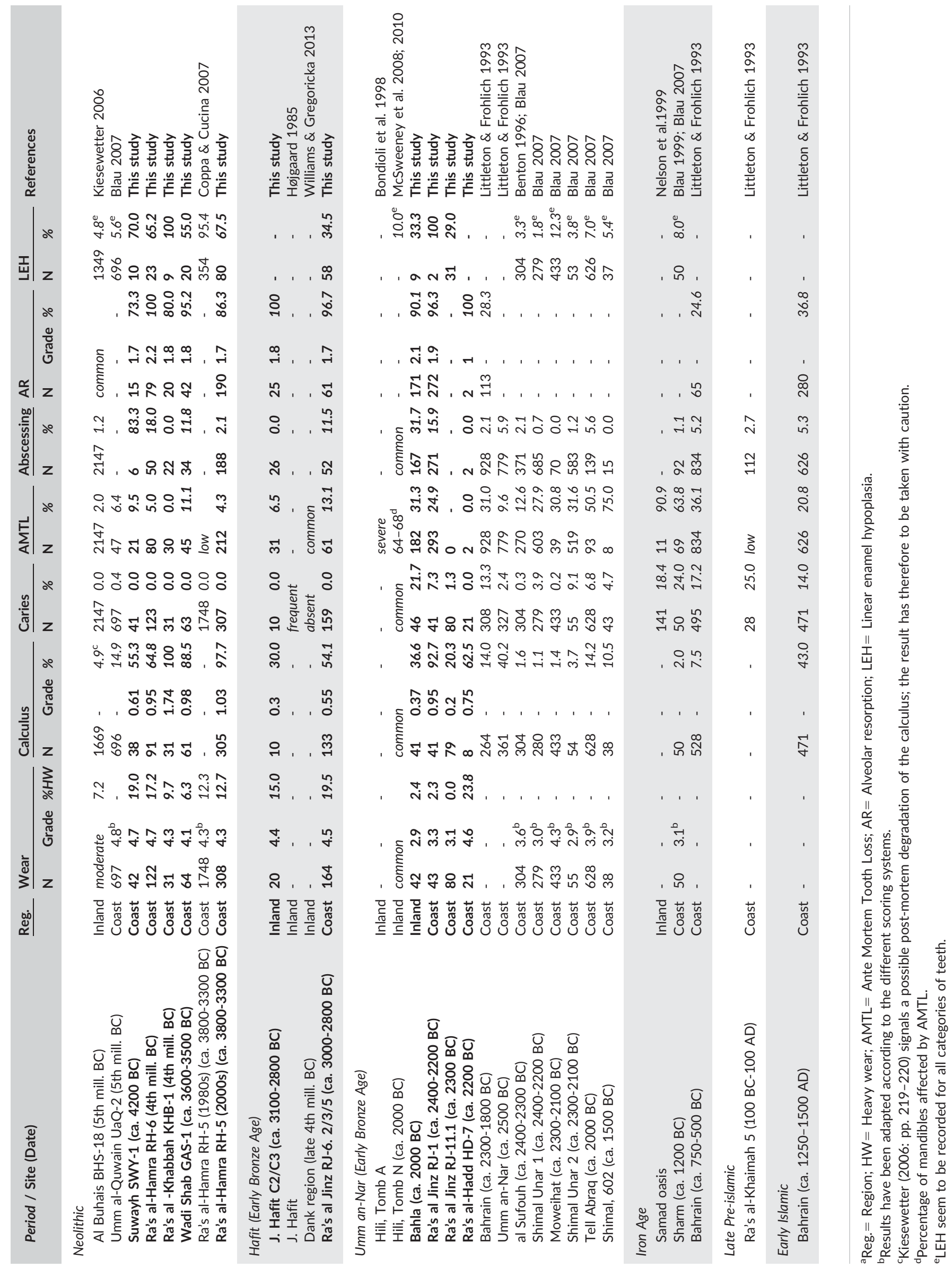


attributed to carbohydrate consumption is moderate and does not point to an abrupt nutritional change. Our results from RJ-6 rather suggest that the proportion of carbohydrates in the diet was still relatively low but point to increasing diversification of subsistence and resources exploitation. In this regard, paleobotanical analyses from the settlement excavated at HD-6, have evidenced few charred date seeds (Azzarà, 2012), suggesting the availability of some agricultural products on the coast from the beginnings of the $3^{\text {rd }}$ millennium BC. However, as no other cultivated crops were associated to these remains (Azzarà, 2015), the cultivated nature of these dates may be questioned, as well as their geographic origin. Therefore, we may consider that those fruits presence result from interactions with remote groups rather than being locally harvested.

\subsubsection{Hafit inland population}

Our sample from Jebel Hafit is small and the poor state of preservation did not allow recording all the parameters retained in the present study for all teeth categories, which weakens the results concerning this group. The study sample displays high rates of dental wear and periodontal disease, moderate calculus, low frequencies of abscessing and AMTL, and no caries are recorded. For most of the parameters except calculus, these results do not diverge significantly from the Neolithic coastal samples and still denote a diet with abrasive component and low carbohydrate intakes. Nonetheless, as for coastal samples, the pattern of pathological afflictions across the mandibular teeth may hint at dietary changes, as premolars and molars seem to be more affected by abscesses, AMTL and alveolar resorption than anterior teeth, in contrast to the Neolithic samples. For most of the parameters observed, no significant difference in mean rates is found between coastal and inland samples.

Few comparative data are available inland for the Hafit period. As noted by Benton in her doctoral research (Benton, 2006, pp. 254), of the nearly 70 excavated Hafit-tombs inland, few have delivered skeletal remains that have been adequately published. In fact, the burial practices, taphonomic processes, and looting, have damaged human remains and their poor state of preservation is recurrent, making it difficult to carry out systematic studies on sufficient samples. Moreover, due to their above-ground nature and visibility in the landscape, Hafit tombs have frequently been re-used in later periods and may therefore contain commingled remains of individuals buried during a long time span that may exceed millennia (e.g. Tomb S002-001 at Al Khutma, Williams \& Gregoricka, 2013). However, some indications on dental status can be found in well dated context from recent excavations carried near Dhank (Oman) by Williams and Gregoricka (2013), although the poor preservation of skeletal remains limited the observations. In the Tomb S002-001 from al Khutma necropolis, an adult skeleton (indiv. B), radiocarbon dated to the late $4^{\text {th }}$ millennium BC, had antemortem loss of several mandibular teeth (right lower premolars and molars, ibid.). In the Tomb S007-003 from Al Khubayb, radiocarbon dated to the first half of the $3^{\text {rd }}$ millennium BC, an adult female (indiv. B), had lost "a significant number of anterior teeth before death", while an older male (indiv. D) presented heavy wear and several AMTL on the anterior dentition, interpreted as occupational or task-related wear
(Williams \& Gregoricka, 2013, pp. 144). To date, no caries have been reported for the Hafit period in this assemblage, and more work is needed to identify subsistence patterns from this community (ibid.). A different picture emerges from a previous study carried out on Jebel Hafit tombs. According to Højgaard (1985), dental pathologies and SEM examination of the dentition from three individuals from Jebel Hafit revealed evidence of many carious lesions (11/12 teeth), and the pattern of striations on the teeth surface pointed at a diet dominated by vegetables, suggesting an agriculturalist way of life for this population. As this conclusion is somewhat contradictory with the results we obtained in the same area, it is necessary to extend the corpus, and to cross several approaches (bioarchaeological, isotopic, archaeological) to better investigate the diversity of subsistence strategies that seems to characterize the Hafit period.

\subsection{5 | Umm an-Nar coastal population}

A distinctive pattern emerges for the coastal groups during the Umm an-Nar period compared to Hafit and Neolithic coastal samples. Umm an-Nar groups display on average significantly lower mean wear and $\mathrm{HW}\left(\chi^{2}=16.6945, \mathrm{df}=1, p<.01\right)$, as well as higher severe AR $\left(\chi^{2}\right.$ $=4.365, \mathrm{df}=1, p=.0367)$ and AMTL frequencies $\left(\chi^{2}=3.8906, \mathrm{df}=1\right.$, $p=.04856)$, and caries $\left(\chi^{2}=4.539, \mathrm{df}=1, p=.0331\right)$. The increase of periapical lesions and AMTL, associated with the presence of carious lesions, points to an increasing part of carbohydrates in the diet. The distribution patterns of AR and AMTL across the mouth, affecting more commonly posterior teeth, are consistent with a more pathogenic diet. Concomitantly, the significant decrease of dental wear suggests a reduced masticatory demand on teeth, and/or less abrasive consistency of the food. Such transformations may reflect an introduction of agricultural products (dates, cereals, and leguminous) that could have contributed to diversify the food with softer supplies, and thus to reduce the masticatory stress on teeth. In accordance with these results, date palm (Phoenix dactylifera) and jujube (Zizyphus sp.) charred seeds have been reported in the settlement at Ra's al-Jinz RJ-2 for the same period, (Costantini \& Audisio, 2001), and testify of the consumption of these fruits by Ra's al-Jinz inhabitants. Moreover, the widespread use of pottery in domestic spheres during the Umm an-Nar period (Méry, 2000) could also have played a role in the diminution of dental wear, by introducing new processing techniques for food preparation; extended periods of cooking and boiling in ceramic vessels could have contributed to soften the food-meat and vegetable-thus reducing the masticatory request, but also to clean the food from abrasive or hard particles. Such explanations are consistent with the significant decrease of micro-fractures observed on the occlusal surfaces of the teeth from the Umm an-Nar period sample (Munoz, 2014).

Some of the dental parameters observed do not diverge significantly between Umm an-Nar and Hafit periods at Ra's al-Jinz (LEH, mean AR, mean calculus, periapical lesions), suggesting some continuity in dietary habits through time. Although the pathologies ascribed to carbohydrates consumption increase significantly in the Umm an-Nar period compared to the Hafit one, the occurrence of caries recorded at Ra's al-Jinz and Ra's al-Hadd for the Umm an-Nar period is significantly lower (2.8\%) than in our inland sample from Bahla (21.7\%). This would 
suggest that carbohydrates-and by extension, agricultural supplies -, although present, did not play a preponderant role in the diet of the group buried along the Arabian Sea during the Umm an-Nar period. According to the zooarchaeological studies carried at RJ-2, the faunal assemblage, largely dominated by marine animals (fish and marine mammals), indicates that the protein intake was based on marine exploitation (Bökönyi, 1992). As a whole, these data point to a rather mixed subsistence, based both on the exploitation of local marine resources and the acquisition of inland agricultural products.

In the Gulf region, similar low caries frequencies have been reported in the population buried in communal tombs from Umm anNar Island (2.4\%, Littleton \& Frohlich, 1993) for which zooarchaeological studies (Hoch, 1995) and isotopic analyses (Gregoricka, 2013b) have confirmed a subsistence mainly based on marine-based food. According to Blau (2007) caries frequencies reported for other Bronze Age coastal populations from the southern Persian Gulf vary from $0.2 \%$ (Moweihat) to $9.1 \%$ (Shimal, Unar 2), whereas AMTL frequencies show a wide range, with reported rates varying from $12.6 \%$ (al-Sufouh) to $75 \%$ (Shimal, T.602). Analyses of dental pathologies from Tell Abraq and Moweihat, showed a high degree of dental wear, high frequency of AMTL and important calculus deposits. These conditions were respectively interpreted as evidences of regular consumption of stoneground cereal grains, agricultural diet rich in carbohydrates and sugars, and increased dependence on plant domesticates (Blau, 2007). Blau (2007) concluded by emphasizing that although a diversity of patterns emerges from the Gulf region, an overall trend in oral pathologies is observed, with a decrease in the prevalence of LEH and calculus, and an increase of caries and AMTL. In addition to oral pathologies, geochemical analyses carried by Gregoricka (2013b) on coastal populations from the Gulf suggested a great dietary variability in the Umm an-Nar period, perhaps related to a multitude of subsistence strategies. According to these analyses, the $\delta^{13} \mathrm{C}$ values observed at Tell Abraq and Moweihat, suggest that the diet was more terrestrially based than on other coastal sites (Umm an-Nar Island), with an emphasis on plants domesticates agriculture and $\mathrm{C}_{4}$-consuming domesticated animals. In conclusion, the relative diversity of patterns in oral pathologies observed in eastern Arabia may reflect the variable but increased integration of agricultural products into the diet from the second half of the $3^{\text {rd }}$ millennium BC.

\subsubsection{Umm an-Nar inland population}

Dental pathologies from the group buried at Bahla (ca. 2000 BC) present significant differences compared to the other studied groups. While displaying moderate dental wear, calculus, and LEH, this population show high alveolar resorption, periapical lesions, and caries frequencies and very high AMTL. As a whole, these data suggest that agricultural products with high carbohydrate content were already a major component in the diet of this oasis population, pointing toward a significant agricultural production. Indeed, similar caries frequencies are reported among later agricultural populations from the Persian Gulf (Sharm: 24\%, ca. 1200 BC, Blau 2007; Ra's al-Khaimah 5: 25\%, Preislamic period, Littleton \& Frohlich, 1993). Agriculturalists from Samad presented high caries frequencies during the Iron Age (18.4\%, 32.4\% corrected, Nelson, Lukacs \& Yule, 1999), while those from Bahrain display still high but lower frequencies (Bronze Age: 13.3\%, Iron Age: 17.2\%, Islamic period: 14\%, Littleton \& Frohlich, 1993). For the Umm an-Nar period, the evaluation of dental pathologies from individuals buried in Tomb A at Hili North (UAE, Bondioli, Coppa \& Macchiarelli, 1998) indicated an impressive number of caries-related AMTL, interpreted as a date consumption effect. Such a high prevalence of AMTL is also mentioned for the Tomb $\mathrm{N}$ from Hili, dating from the very end of the $3^{\text {rd }}$ millennium BC, where $64 \%$ to $68 \%$ of the mandible had missing teeth (McSweeney, Méry, \& Macchiarelli, 2008; McSweeney, Méry \& Al-Tikriti, 2010). However, the moderate caries frequencies (6\%) recorded lead authors to relativize the role of date consumption for this population, emphasizing the multi-factorial etiology of AMTL. In our sample from Bahla, the combination of high frequencies of caries, abscesses and alveolar resorption with moderate rates of wear and calculus, strongly support the idea that AMTL were caries-related, rather than induced by calculus or attrition (Lukacs, 1989).

Our results emphasize the significant agricultural base of Umm anNar society, at least inland, as already suggested by Al-Jahwari (2009), as it would represent an evidence of the development of fully integrated agriculture at the end of the $3^{\text {rd }}$ millennium BC. Further study of samples from the Hafit period and inland regions are necessary to precise the rhythm of agricultural development in Eastern Arabia. To date, our analyses suggest that expansion of oases systems truly succeeded from the second half of the third millennium BC. Their introduction and the innovations required may have appeared quite early (late $4^{\text {th }}$ early $3^{\text {rd }}$ mill. $\mathrm{BC}$ ) but the evidence of the impact of farming on subsistence and dental health are clearly observable, in our sample, from the Umm an-Nar period. Dental data suggest a gradual setting up of agricultural economy during the Hafit period, involving mixed subsistence strategies. Regardless of the autochtonous or allochtonous origin of cultivated crops and related know-how (irrigation and cultivation techniques), it is likely that the adaptation of this production system to local conditions has undergone phases of "trial and error" before attaining efficiency. The development of oases systems was most likely a complex process, affected by a large geographical variability related to local environmental constraints (Tosi, 1975); groups with different economic orientations have certainly coexisted. Therefore, the diet of inland groups might have relied on a wide spectrum of resources: gardens, husbandry, gathering and hunting. Such diversity of subsistence strategies may explain the controversial interpretation of spatial analyses based on the distribution of Hafit-type tombs (sedentary agriculturalists/nomad pastoralists; Giraud, 2009 contra Deadman, 2012).

\subsection{Implications for mobility and interregional exchanges}

As a whole, the oral conditions observed in the Neolithic coastal population reflect alimentary practices mainly composed by unprocessed food with an abrasive consistency, few carbohydrates, and frequent stress episodes evocating possible nutritional deficiencies. This result is in accordance with geochemical analyses from human remains from RH-5 (Zazzo, Munoz \& Saliége, 2014) and RH-6 (Zazzo et al., 2016) 
that revealed a subsistence principally oriented toward marine and coastal resources, indicating low mobility or almost restricted to the coastal environment.

Conversely, the diversification of diet evidenced by our evaluation of dental pathologies for the first half of the $3^{\text {rd }}$ millennium BC support the hypothesis of an increase of exchanges networks and a more mobile way-of-life of Hafit groups. Such diversification fits well with the territorial expansion observed during the Hafit Period and is perceptible throughout the location of funerary monuments. Interestingly, the diseases commonly attributed to agricultural-based subsistence are clearly observable in our samples from the Umm an-Nar Period. These data suggest that in spite of an early development of agricultural systems attested by archaeological evidence, its spread could have been gradual and limited to inland areas during the early Hafit Period, although our small inland Hafit sample did not evidence such agricultural-based diet pattern. Therefore, in spite of an apparent homogeneity in the material culture and funerary traditions, as well as coastal-interior exchanges networks ascertained by artefacts (copper, shells, beads and ceramics), Hafit communities probably had a diversity of dietary orientations, although more precise conclusion is limited by the lack of comparative data from the interior. Further work is therefore required to better understand their subsistence strategies and patterns of mobility.

Regarding the Umm an-Nar Period, the comparison of caries frequencies in the communities from Ra's al-Hadd, Ra's al-Jinz and Bahla, suggests that despite availability of agricultural supplies on the eastern coast of Oman after the mid- $3^{\text {rd }}$ millennium BC, the individuals buried in communal tombs on the coast had a mixed diet relying on both marine and agricultural food. Seasonal mobility and/or a relative sedentism with an intensification of interregional exchange networks implying agricultural supplies could explain this mixed subsistence. Besides, it might reveal different degrees of participation of local communities to regional exchanges networks during the Umm an-Nar period; in other words, different communities might have had different access to trading networks and therefore to agricultural supplies possibly involved in these exchanges. In contrast, dental diseases of individuals buried at Bahla, who lived around 2000 BC reflect an economy heavily oriented toward agricultural resources suggesting low mobility. This is in accordance with strontium isotopic analyses carried by Gregoricka (2013a) on six Umm an-Nar tombs in the Gulf region; the little isotopic variability indicates a relative low mobility of these groups, although they were integrated in intense interregional trade interactions.

\section{5 | CONCLUSION}

Temporal changes and regional variability in subsistence strategies and lifestyles were investigated using dento-alveolar conditions from individuals buried in 11 funerary complexes from the Late Neolithic (ca. 4500 BC) to the end of the Umm an-Nar period (ca. 2000 BC), located on the eastern coast and the interior of the Oman peninsula. The large set of dental indicators employed allowed exploring the relationships between pathologies with multifactorial etiologies, and better characterize subsistence patterns, providing valuable information on dietary practices and lifestyles of prehistoric communities preceding and following the rise of oases agriculture in the region.

While dental conditions in Neolithic coastal groups reflect a heavy dependence toward marine resources and low carbohydrate consumption, some significant changes in oral pathologies from the Hafit period suggest that this groups experienced a modification in their lifestyle with a probable diversification of the diet and nutritional practices, but still no markers of high carbohydrate consumption are found in the coastal and in the inland samples.

The impact of agriculture development on dental health appears clearly only from the Umm an-Nar period, with disparities between coastal and inland groups, the later showing a higher dependence on agricultural supplies. Conversely, oral conditions from the coastal group buried at Ra's al-Jinz RJ-1 and RJ-11, dating from ca. 2600-2200 BC, still denote a subsistence economy based on fishing. The transition to agricultural systems seems to have been progressive, and although several changes are perceptible as soon as the Hafit period, the values observed in our sample indicate tenuous changes in subsistence rather than abrupt transformation on the diet and nutritional practices. Moreover, our samples denote a diversity of subsistence strategies characterizing the populations during the EBA, testifying of their continuous adaptation to specific environments.

Although the preservation of human remains in the region is poor, bones and teeth are of considerable interest to improve our knowledge on the subsistence strategies of prehistoric communities over time. The record of dental pathologies has proven to be a valuable tool to offer evidence of dietary habits and indications on lifestyles. Further work is required to increase the sample size and better explore the geographical trends in subsistence patterns, especially in areas where agriculture is alleged to have raised precociously. Geochemical analyses carried on human remains will also allow completing the picture emerging from this study.

\section{ACKNOWLEDGMENTS}

This study is part of a PhD dissertation, supported by a scholarship from the University of Paris 1 Panthéon-Sorbonne. (France) The field researches have been sponsored by the Ministry of Foreign Affairs (France), the CNRS (UMR 7041 ArScAn, VEPMO Team, France), the Ministry of Culture and Heritage of the Sultanate of Oman, and the Fyssen Foundation (Collaboration, Research Grant: A. Zazzo). This article has also been made possible thanks to a post-doctoral fellowship from the Labex Les passés dans le présent, Investissements d'avenir, réf. ANR-11-LABX-0026-01. The author is very grateful to the late S. Cleuziou and M. Tosi, formerly co-directors of the Joint Hadd Project, to A. Coppa, and to F. Cavulli, V. Charpentier, G. Santini, and D. Usai, who have entrusted the study of human remains from sites they have excavated. Special thanks are due to all those who have collaborated with the author on the recent burials excavation at Ra's al-Hamra RH-5 and RH-6, Ra's al-Hadd HD-7, Ra's alJinz RJ-1 and Bahla. The author wish to thank A. Zazzo for his support and advices during the preparation of this article, V. M. Azzarà 
and K. D. Williams for their kind review. Finally the author thank the three anonymous referees whose helpful comments greatly improved this article.

\section{ORCID}

Olivia Munoz (iD) http://orcid.org/0000-0002-6180-194X

\section{REFERENCES}

Al-Jahwari, N. S. (2009). The agricultural basis of Umm an-Nar society in the northern Oman peninsula (2500-2000 BC). Arabian Archaeology and Epigraphy, 20, 122-133.

Al-Jahwari, N. S. (2015). The Hafit period in the Oman Peninsula: Cultural and economic changes Proceedings of the Symposium: The Archaeological Heritage of Oman, Unesco, Paris, September 7th, 2012. Muscat: Ministry of Heritage and Culture (Oman), UNESCO.

Azzarà, V. M. (2012). The organisation of food processing at HD-6 (Sultanate of Oman). In R. Matthews \& J. Curtis (Eds.), Proceedings of the 7th International Congress on the Archaeology of the Ancient Near East, 12-16 April 2010, the British Museum and UCL, London (pp. 251268). Wiesbaden: Harrassowitz Verlag.

Azzarà, V. M. (2015). L'architecture domestique et l'organisation de la maisonnée dans la péninsule d'Oman à l'âge du Bronze ancien. (PhD Thesis), Université de Paris 1 Panthéon-Sorbonne, Paris.

Beech, M. (2004). In the Land of the Ichthyophagi. Modelling fish exploitation in the Arabian Gulf and Gulf of Oman from the 5th millennium BC to the Late Islamic period. BAR International Series 1217.

Beech, M., \& Shepherd, E. (2001). Archaeobotanical evidence for early date consumption on Dalma Island, United Arab Emirates. Antiquity, 75, 83-89.

Benton, J. (2006). Burial Practices of the third millennium BC in the Oman peninsula: A Reconsideration. (PhD thesis), University of Sydney, Sidney.

Biagi, P. (1999). Excavations at the shell-midden of RH6 1986-1988 (Muscat, Sultanate of Oman). Al-Rafidan, XX, 57-84.

Biagi, P., \& Nisbet, R. (1992). Environmental history and plant exploitation at the aceramic sites of $\mathrm{RH} 5$ and $\mathrm{RH} 6$ near the mangrove swamp of Qurm (Muscat - Oman). Bulletin de la Société Botanique de France, 139, 571-578.

Blau, S. (2007). Skeletal and dental health and subsistence change in the United Arab Emirates. In M. N. Cohen \& G. M. M. Crane-Kramer (Eds.), Ancient health: Skeletal indicators of agricultural and economic intensification (pp. 190-206). Gainesville, FL: University Press of Florida.

Bökönyi, S. (1992). Preliminary Information on the Faunal Remains from Excavations at Ra's al-Junayz (Oman). In C. Jarrige (Ed.), South Asian archaeology, Paris 1989, Monographs in World Archaeology 14 (pp. 45-48). Wisconsin: Prehistoric Press Madison.

Bondioli, L., Coppa, A., \& Macchiarelli, R. (1998). From the coast to the oasis in Prehistoric Arabia: What the human osteodental remains tell us about the transition from a foraging to the exchange economy? Evidence from Ra's al-Hamra (Oman) and Hili North (U.A.E.). In G. Afanas'ev, S. Cleuziou, J. Lukacs, \& M. Tosi (Eds.), The Prehistory of Arabia and Oceania, Proceedings of the XIIIth Congress of the IUPPS, Forli, 8-14 September 1996 (pp. 229-234). Forli: ABACO.

Brothwell, D. R. (1981). Digging up bones (3rd Edition). Oxford: Oxford University Press (British Museum Natural History).
Buikstra, J. E., \& Ubelaker, D. H. (1994). Standards for data collection from human skeletal remains. Fayetteville, Arkansas: Arkansas Archaeological Survey Research Series No. 44.

Cavulli, F., \& Scaruffi, S. (2008). Stone vessels from KHB-1, Ja'lān region, Sultanate of Oman. Proceedings of the Seminar for Arabian Studies, 38, 89-92.

Charlier, P., Charlier, P., Huynh-Charlier, I., Munoz, O., Billard, M., Brun, L., \& Lorin de la Grandmaison, G. (2010). The microscopic (optical and SEM) examination of dental calculus deposits (DCD). Potential interest in forensic anthropology of a bio-archaeological method. Legal Medicine, 12, 163-171.

Charpentier, V., Blin, O., \& Tosi, M. (1998). Un village de pêcheurs néolithiques de la péninsule d'Oman: Suwayh 2 (SWY-2), première campagne de fouille. Proceedings of the Seminar for Arabian Studies, 28, 21-38.

Charpentier, V., Marquis, P., \& Pellé, E. (2003). La nécropole et les derniers horizons $V^{e}$ millénaire du site de Gorbat al-Mahar (Suwayh, SWY-1, Sultanat d'Oman): Premiers résultats. Proceedings of the Seminar for Arabian Studies, 33(33), 11-19.

Cleuziou, S. (2005). Pourquoi si tard? Nous avons pris un autre chemin In J. Guilaine (Ed.), Aux marges des grands foyers du néolithique. Périphéries débitrices ou créatrices? (pp. 123-148). Paris: Errance.

Cleuziou, S. (2007). Evolution toward Complexity in a Coastal Desert Environment. The Early Bronze Age in the Ja'alan, Sultanate of Oman. In T. A. Kohler \& S. Van Der Leeuw (Eds.), The model-based archaeology of socionatural systems (pp. 213-231). Santa Fe: SAR Press.

Cleuziou, S. (2009). Extracting wealth from a land of starvation by creating social complexity: A dialogue between archaeology and climate? Comptes Rendus Géoscience, 341, 726-738.

Cleuziou, S., \& Costantini, L. (1980). Premiers éléments sur l'agriculture protohistorique de l'Arabie orientale. Paléorient, 6, 245-251.

Cleuziou, S., \& Costantini, L. (1982). A l'origine des oasis. La Recherche, 137, 1180-1182.

Coppa, A., \& Cucina, A. (2007). The Anthropological Analysis. Journal of Oman Studies, 14 (pp. 203-342). Muscat: Ministry of Heritage and Culture, Sultanate of Oman.

Costantini, L., \& Audisio, P. (2001). Plant and insect remains from the Bronze Age site of Ra's al-Jinz (RJ-2), Sultanate of Oman. Paléorient, 26, 143-156.

Deadman, W. M. (2012). Defining the Early Bronze Age landscape: A remote sensing-based analysis of Hafit tomb distribution in Wadi Andam, Sultanate of Oman. Arabian Archaeology and Epigraphy, 23, 26-34.

El-Mahi, A. T. (2000). Traditional fish preservation in Oman: The seasonality of a subsistence strategy. Proceedings of the Seminar for Arabian Studies, 30, 99-113.

Eshed, V., Gopher, A., \& Hershkovitz, I. (2006). Tooth wear and dental pathology at the advent of agriculture: New evidence from the Levant. American Journal of Physical Anthropology, 130, 145-159.

Gaultier, M., Guy, H., Munoz, O., Tosi, M., \& Usai, D. (2005). Settlement structures and cemetery at Wadi Shab-GAS1, Sultanate of Oman: Report on the 2002 and 2003 field seasons. Arabian Archaeology and Epigraphy, 16, 1-20.

Giraud, J. (2009). The evolution of settlement patterns in the eastern Oman from the Neolithic to the Early Bronze Age (6000-2000 BC). Comptes Rendus Géoscience, 341, 739-749.

Goodman, A. H., \& Rose, J. C. (1991). Dental enamel hypoplasias as indicators of nutritional status. In M. A. Kelley \& C. S. Larsen (Eds.), Advances in dental anthropology (pp. 279-293). New-York: WileyLiss. 
Green, N., \& Copp, A. (2014). Neural tube defects. Annual Review of Neuroscience, $37,221-242$.

Gregoricka, L. A. (2013a). Residential mobility and social identity in the periphery: Strontium isotope analysis of archaeological tooth enamel from southeastern Arabia. Journal of Archaeological Science, 40, 452464.

Gregoricka, L. A. (2013b). Geographic Origins and Dietary Transitions During the Bronze Age in the Oman Peninsula. American Journal of Physical Anthropology, 152, 353-369.

Hammer, Ø., Harper, D. A. T., \& Ryan, P. D. (2001). PAST: Paleontological Statistics software package for education and data analysis. Paleontologia Electronica, 4, 1-9.

Hoch, E. (1995). Animal bones from the Umm an-Nar settlement. In Frifelt $\mathrm{K}$ (Ed.), The island of Umm An-Nar, Vol. 2. The third millennium settlement (pp. 249-256). Munskgaard: JASP XXVI: 2.

Højgaard, K. (1981). Dentition on Umm an-Nar, c. 2500 B.C. Proceedings of the Seminar for Arabian Studies, 11, 31-36.

Højgaard, K. (1985). SEM (scanning electron microscopic) examination of teeth from the third millennium BC excavated in Wadi Jizzi and Hafit. In J. Schotsmans \& M. Taddei (Eds.), South Asian Archaeology 1983 (pp. 151-156). Naples: Instituto Universitario Orientale.

Kiesewetter, H. (2006). Analyses of the Human Remains from the Neolithic Cemetery at al-Buhais 18 (Excavations 1996-2000). In H.-P. Uerpmann, M. Uerpmann, \& S. A. Jasim (Eds.), The Archaeology of Jebel al-Buhais, Volume 1 - Funeral Monuments and Human Remains from Jebel al-Buhais (pp. 103-380). Tübingen: Kerns Verlag.

Larsen, C. S., Shavit, R., \& Griffin, M. C. (1991). Dental Caries Evidence for Dietary Change: An Archaeological Context. In Kelley, M.A. \& Larsen, C.S. (Eds.), Advances in dental anthropology (pp.179-202). New York: Wiley-Liss.

Littleton, J., \& Frohlich, B. (1993). Fish-eaters and farmers: Dental pathology in the Arabian Gulf. American Journal of Physical Anthropology, 92, 427-447.

Lukacs, J. R. (1989). Dental paleopathology: Methods for reconstructing dietary patterns. In M.-Y. Iscan \& K. A. R. Kennedy (Eds.), Reconstruction of life from the skeleton (pp. 261-286). New-York: Alan R. Liss.

Lukacs, J. R. (1992). Dental Paleopathology and Agricultural Intensification in South Asia: New Evidence from Bronze Age Harappa. American Journal of Physical Anthropology, 87, 133-150.

Maat, G. J., \& Van der Velde, E. A. (1987). The caries-attrition competition. International Journal of Anthropology, 2, 281-292.

Macchiarelli, R. (1989). Prehistoric "fish-eaters" along the Eastern Arabian Coasts: Dental variation, morphology, and oral health in the Ra's alHamra community (Qurum, Sultanate of Oman, 5th-4th Millennia BC). American Journal of Physical Anthropology, 78, 575-594.

McSweeney, K., Méry, S., \& Macchiarelli, R. (2008). Rewriting the end of the Early Bronze Age in the United Arab Emirates through the anthropological and artefactual evaluation of two collective Umm anNar graves at Hili (eastern region of Abu Dhabi). Arabian Archaeology and Epigraphy, 19, 1-14.

McSweeney, K., Méry, S., \& Al-Tikriti, W. Y. (2010). Life and Death in an Early Bronze Age community from Hili, Al Ain, UAE. In L. Weeks (Ed.), Death and burial in Arabia and beyond (pp. 45-54). Oxford: BAR international Series 2107.

Marcucci, L. G., Badel, E., Genchi, F., Munoz, O., Todero, A., \& Tosi, M. (2014). New investigations at the prehistoric shell midden of Ra's alHamra 6 (Sultanate of Oman): Results of the 2012 and 2013 excavation seasons. Proceedings of the Seminar for Arabian Studies, 44, 235-256.

Marcucci, L. G., Genchi, F., Badel, E., \& Tosi, M. (2011). Recent investigations at the prehistoric site RH-5 (Ra's al-Hamra, Muscat, Sultanate of Oman). Proceedings of the Seminar for Arabian Studies, 41, 201222.

Méry, S. (2000). Les céramiques d'Oman et l'Asie moyenne. Une archéologie des échanges à l'âge du bronze. Paris: CNRS.

Munoz, O. (2011). Etude anthropologique des restes humains des cairns C2 et C3 du Jebel Hafit (1977). In S. †Cleuziou, S. Méry, \& B. Vogt (Eds.), Protohistoire de l'oasis d'al-Aïn, Travaux de la Mission archéologique française à Abou Dhabi (Emirats Arabes Unis), Vol. 1, Les sépultures de l'âge du Bronze (pp. 218-224). Oxford: BAR S2227 International Series.

Munoz, O. (2014). Pratiques funéraires et paramètres biologiques dans la péninsule d'Oman du Néolithique à la fin de l'âge du Bronze ancien ( $V$ Ille mill. avant notre ère). (PhD Thesis), Université de Paris 1 Panthéon-Sorbonne/Università di Roma La Sapienza, Paris.

Munoz, O. (2015). La fabrique des ancêtres. Complexification sociale et sépultures collectives à l'âge du Bronze ancien dans la péninsule d'Oman. In G. Delaplace \& F. Valentin (Eds.), Le funéraire. Mémoire, protocoles, monuments (pp. 255-265). Paris: Editions de Boccard, Maison Archéologie et Ethnologie.

Munoz, O., Ghazal, R. O., \& Guy, H. (2012). Use of ossuary pits during the Umm an-Nar period: New insights on the complexity of burial practices from the site of Ra's al-Jinz (RJ-1), Oman. In G. Gernez \& J. Giraud-Gernez (Eds.), Aux marges de l'archéologie. Hommage à serge cleuziou (pp. 451-467). Paris: Travaux de la maison René-Ginouvès, De Boccard.

Munoz, O., Scaruffi, S., \& Cavulli, F. (2010). The burials of the middle Holocene settlement of KHB-1 (Ra's al-Khabbah, Sultanate of Oman). In L. Weeks (Ed.), Death and burial in arabia and beyond (pp. 25-32). Oxford: BAR International Series 2107.

Nelson, G. C., Lukacs, J. R., \& Yule, P. (1999). Dates, caries, and early tooth loss during the Iron Age of Oman. American Journal of Physical Anthropology, 108, 333-343.

Potts, D. T. (2001). Before the Emirates: An Archaeological and Historical Account of Developments in the Region c. 5000 BC to 676 AD. In P. Hellyer \& I. al Abed (Eds.), United Arab Emirates. A new perspective (pp. 28-69). London: Trident Press.

Salvatori, S. (2007). The Prehistoric Graveyard of Ra's al-Hamra 5, Muscat, Sultanate of Oman. The Journal of Oman Studies, 14, 5-202.

Santini, G. (1992). Analisi dei caracteri dominanti per la definizione dei rituale nelle necropoli preistoriche e protostoriche della Penisola di Oman. (Tesi di Dottorato Dottorato di ricerca in Archeologia), Istituto Universitario Orientale, Universita di Napoli, Napoli.

Selwood, K. (2010). Is there a definable dental pathology signature among peoples consuming marine-dependent diets in the Pacific?. Homo - Journal of Comparative Human Biology, 61, 217.

Smith, B. H. (1984). Patterns of Molar Wear in Hunter-Gatherers and Agriculturalists. American Journal of Physical Anthropology, 63, 39-56.

Stephan, R. M. (1966). Effects of different types of human foods on dental health in experimental animals. Journal of Dental Research, 45, 1551-1561.

Tang, N., Le Cabec, A., \& Antoine, D. (2015). Dentine and Cementum Structure and Properties. In J.D. Irish \& Scott G. R. (Eds.), A companion to dental anthropology (pp. 204-222), Hoboken: Wiley Blackwell.

Tayles, N., Domett, K., \& Nelsen, K. (2000). Agriculture and dental caries? the case of rice in Prehistoric Southeast Asia. World Archaeology, 32, 68-83.

Tengberg, M. (2008). The Exploitation of Wood at Neolithic al-Buhais 18, Sharjah (UAE): Results of the Charcoal Analysis. In H. P. Uerpmann, M. Uerpmann, \& S. A. Jasim (Eds.), The archaeology of Jebel AlBuhais, Volume 2 - The natural environment of Jebel Al-Buhais: Past and present (pp. 83-96). Tübingen: Kerns Verlag. 
Tengberg, M. (2012). Beginnings and early history of date palm garden cultivation in the Middle East. Journal of Arid Environments, 86, 139147.

Tosi, M. (1975). Notes on the distribution and exploitation of natural resources in ancient Oman. Journal of Oman Studies, 1, 187-206.

Turner, C. G. (1979). Dental anthropological indications of agriculture among Jomon in central Japan. American Journal of Physical Anthropology, 51, 619-636.

Uerpmann, M. (2003). The Dark Millennium - Remarks on the Final Stone Age in the Emirates and Oman. In D. T. Potts, H. Al Nabooda, \& P. Hellyer (Eds.), Archaeology of the United Arab Emirates (pp. 7481). London: Trident Press.

Uerpmann, H.-P., Uerpmann, M., \& Jasim, S. A. (Eds.). (2008). The archaeology of Jebel Al-Buhais, Volume 2 - The natural environment of Jebel Al-Buhais: Past and present (Vol. 2). Tübingen: Kerns Verlag.

Usai, D. (2006). A fourth-millennium BC Oman site and its context: Wadi Shab-GAS1. Proceedings of the Seminar for Arabian Studies, 36, 275-288.

Willcox, G. (1995). Some plant impressions from Umm an-Nar Island. In K. Frifelt (Ed.), The island of Umm an-Nar : the third millenium settlement (pp. 257-259). Aarhus: Aarhus University Press.

Willcox, G., \& Tengberg, M. (1995). Preliminary report on the archaeobotanical investigations at Tell Abraq with special attention to chaff impressions in mud brick. Arabian Archaeology and Epigraphy, 6, 129138.

Williams, K. D., \& Gregoricka, L. A. (2013). The Social, Spatial, and Bioarchaeological Histories of Ancient Oman project: The mortuary landscape of Dhank. Arabian Archaeology and Epigraphy, 24, 134150.

Zazzo, A., Munoz, O., \& Saliège, J.-F. (2014). Diet and mobility in a late Neolithic population of coastal Oman inferred from radiocarbon dating and stable isotope analysis. American Journal of Physical Anthropology, 153, 353-364.

Zazzo, A., Munoz, O., Badel, E., Beguier, I., Genchi, F., \& Marcucci, L. G. (2016). A Revised radiocarbon chronology of the Aceramic Shell Midden of Ra's Al-Hamra 6 (Muscat, Sultanate of Oman): Implication for occupational sequence, marine reservoir age, and human mobility. Radiocarbon, 58, 383-395.

How to cite this article: Munoz O. Transition to agriculture in South-Eastern Arabia: Insights from oral conditions. Am J Phys Anthropol. 2017;00:1-18. https://doi.org/10.1002/ajpa.23307 